\title{
Paleoclimatic control of biogeographic and sedimentary events in Tethyan and peri-Tethyan areas during the Oxfordian (Late Jurassic)
}

\author{
F. Cecca ${ }^{\mathrm{a}, *}$, B. Martin Garin ${ }^{\mathrm{b}, \mathrm{c}}$, D. Marchand ${ }^{\mathrm{d}}$, B. Lathuiliere ${ }^{\mathrm{b}}$, A. Bartolini ${ }^{\mathrm{a}}$

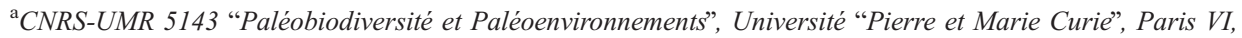 \\ Laboratoire de Micropaléontologie, case 104. 4, Place Jussieu 75252 Paris 05, France \\ ${ }^{\mathrm{b}}$ UMR CNRS 7566 G2R (Géologie et Gestion des Ressources minérales et énergétiques), Université Henri Poincaré, \\ Nancy I, BP 239, 54506 Vandoeuvre-lès-Nancy Cedex, France \\ 'Institut für Geologie der Universität Bern, Baltzerstrasse 1, 3012 Bern, Switzerland \\ ${ }^{\mathrm{d}} U M R$ CNRS 5561 Biogeosciences, Université de Bourgogne, 6, Boulevard Gabriel, 2100 Dijon, France
}

Received 18 June 2003; received in revised form 21 October 2004; accepted 11 March 2005

\begin{abstract}
The paleobiogeographical distribution of Oxfordian ammonites and coral reefs in northern and Central Europe, the Mediterranean area, North and East Africa, and the Middle East and Central Asia is compared with the distribution in time and space of the most important lithofacies. Interest in the Oxfordian is focused on changes in facies and in biogeographical patterns that can be interpreted as the results of climatic events. Paleotemperature trends inferred from oxygen isotopes and paleoclimatic simulations are tested against fossil and facies data. A Late Callovian-Early Oxfordian crisis in carbonate production is indicated by the widespread absence of Lower Oxfordian reefal formations. There is a gap (hiatus) in deposition on epicontinental platforms, with Middle Oxfordian deposits resting paraconformably on Upper Callovian, while shales accumulated in adjacent intracratonic basins. Simultaneously, in Mediterranean Tethys, radiolarites accumulated in deep troughs while Rosso Ammonitico facies formed on pelagic swells. However, deposition on swells was also discontinuous with numerous gaps (hiatuses) and sequences that are much reduced in thickness. Middle Callovian deposits are generally overlain by Middle Oxfordian limestones. The dearth of carbonates is consistent with a cooling event lasting about $1 \mathrm{My}$. By the middle Oxfordian a warming, leading to "greenhouse" type conditions, is suggested on the basis of both biogeographical (mostly coralreef distribution) and geochemical data. Carbonates spread onto an extensive European platform while radiolarites reached a maximum development in the Mediterranean Tethys. Two distinct latitudinal belts, with seemingly different accumulation regimes, are therefore inferred. Similar latitudinal belts were also present in the late Oxfordian, when carbonates were widespread. The distribution of reefal facies in the late Oxfordian-early Kimmeridgian fits relatively well with GCMs simulations that imply low rainfall in the Tethyan Mediterranean area and slightly higher precipitation in central and northern Europe. Local salinity variations, reflecting more arid or humid conditions, may bias the paleotemperature signal inferred from
\end{abstract}

\footnotetext{
* Corresponding author. Fax: +331442738 31 .

E-mail address: cecca@ccr.jussieu.fr (F. Cecca).
} 
$\delta^{18} \mathrm{O}$ values. Biogeographical and facies distributions, combined with $\delta^{18} \mathrm{O}$ values, unravel the ambiguity and support a Late Callovian-Early Oxfordian cooling followed by warming in the later Oxfordian.

(C) 2005 Published by Elsevier B.V.

Keywords: Paleobiogeography; Paleoclimates; Ammonites; Corals; Oxfordian; Tethys

\section{Introduction}

Biogeographical and geochemical research in Europe over the last two decades has provided evidence for important climatic fluctuations in the Jurassic period and despite some early assertions based on biogeographical data (e.g. Haug, 19081911), geological and paleontological data traditionally point to a warm, equable climate for at least the Late Jurassic. However, although geological evidence may be sparse or unconvincing (Price, 1999) simulations of climatic regimes using General Circulation Models (GCMs), do not rule out the seasonal formation of ice caps in particular periods of the Late Jurassic-Early Cretaceous (Moore et al., 1992a,b; Ross et al., 1992; Valdes and Sellwood, 1992; Sellwood and Valdes, 1997; Sellwood et al., 2000).

For the Late Jurassic, global biogeochemical models predict high $p \mathrm{CO}_{2}$ levels (Berner, 1994) and increasing atmospheric $\mathrm{CO}_{2}$ levels in the Oxfordian are supported by higher plant biomarker changes (van Aarssen et al., 2000). On the basis of paleotemperature values calculated on oxygen isotopes of skeletal material from tropical seawater, Veizer et al. (2000) proposed an icehouse mode for the Late Jurassic. To explain this apparent contradiction (high $p \mathrm{CO}_{2}$ levels and cold climate), these authors suggested decoupling the relationship between atmospheric $\mathrm{CO}_{2}$ and global climate, at least for this interval of the Phanerozoic.

However, because the raw data are sporadically distributed in time both kinds of models produce paleotemperature curves for very coarse chronologic intervals. Although climates in the Jurassic were generally characterized by "greenhouse" type conditions, with greater temporal resolution it appears likely that there were brief climatic fluctuations ("cold snaps") of variable amplitude have probably occurred (Jenkyns et al., 2002; Dromart et al., 2003a).
Within Upper Jurassic strata, Oxfordian deposits are of particular value for testing paleoclimatic reconstructions based on GCMs and geochemistry against geological and paleontological records. Interregional facies variations, and changes in the biogeographical distribution of ammonites and reef corals from mid-latitudes of the Boreal region towards low latitudes of Tethyan areas, and vice versa, are the kinds of phenomena that might be expected to be controlled by paleoclimatic changes (Dromart et al., 2003a,b). The paleoclimatic control on both facies and biotic distributions have been advocated by Weissert and Mohr (1996) and by Bartolini et al. (1996) and is supported by stable isotopes $\left(\delta^{13} \mathrm{C}, \delta^{18} \mathrm{O}\right)$ data, although high-resolution carbon and oxygen isotope data are still insufficient to provide trends for the Late Callovian-Early Oxfordian and most are from condensed sections (Norris and Hallam, 1995; Jenkyns, 1996; Cecca et al., 2001). A distinct, positive carbon isotope excursion, suggesting a major perturbation in the carbon cycle, has been identified in the Middle Oxfordian Transversarium Zone (Jenkyns, 1996; Weissert and Mohr, 1996; Bartolini et al., 1996; Wierzbowski, 2002). A contrasting negative excursion, within the upper part of the Transversarium Zone, has been interpreted as reflecting a sudden release of frozen methane hydrate along continental margins (Padden et al., 2001). This would have amplified the greenhouse climate of the middle Oxfordian, inducing "a thermal maximum" period, similar to that of the late Paleocene.

\subsection{Aims}

The aims of this paper are:

(1) to analyse biogeographical changes in distribution of coral reefs and ammonites during the Oxfordian on the basis of data from Tethyan and peri-Tethyan areas (northern and central Europe, 
the Mediterranean, north and east Africa, the Middle East and Central Asia; Figs. 1 and 2);

(2) to interpret biogeographical data and facies changes in time and space, in terms of climatic changes;

(3) to test temperature trends, as deduced on the basis of oxygen isotope analyses, against facies and paleontological data.

As no precisely calibrated Oxfordian paleogeographical map is available, coral biogeographical data are plotted (Fig. 3) on the map used by Thierry (2000) to represent Early Kimmeridgian paleoenvironments (Fig. 2), the distribution of which roughly match those of the Late Oxfordian.

The faunas analysed are chronologically distributed over an interval of about 5.5 My (Gradstein et al., 2004). The ages assigned to Jurassic ammonite zones are taken from Hardenbol et al. (1998) who used the time scale of Gradstein et al. (1994). These authors regarded zones as of almost equal duration despite the fact that their real duration is unknown and certainly extremely variable. However, this practice permits a semiquantitative approximation of evolutionary rates that is certainly biased but preferable to a lack of any kind of estimation. Correlation between the North American and NW European ammonite chrons (on which this work is based) is far from satisfactory, hence the choice of Hardenbol et al.'s (1998) scheme.

\subsection{Paleogeography}

The paleogeography of the areas considered here is characterized as Tethys, an oceanic domain including the Mesozoic Central Atlantic (here regarded as western Tethys). During the Oxfordian, Tethys separated Europe and Asia to the north from Africa, Arabia, and India to the south. Areas north of Tethys formed part of the Eurasian continent, whereas those to the south were parts of a Western continent (South America, Africa and Arabia) (Fig. 1 and 2) with the northern tip of Eastern Gondwana (Madagascar, India, Australia, Antarctica) separated by a proto-Mozambique sea (Ricou, 1994; Fig. 2). According to the plate positions indicated on the Middle Callovian and Early Kimmeridgian maps of Thierry (2000), the latitudinal interval of the paleogeographic domain here considered ranges from roughly $30^{\circ} \mathrm{S}$ to $45^{\circ} \mathrm{N}$ (Fig. 2).

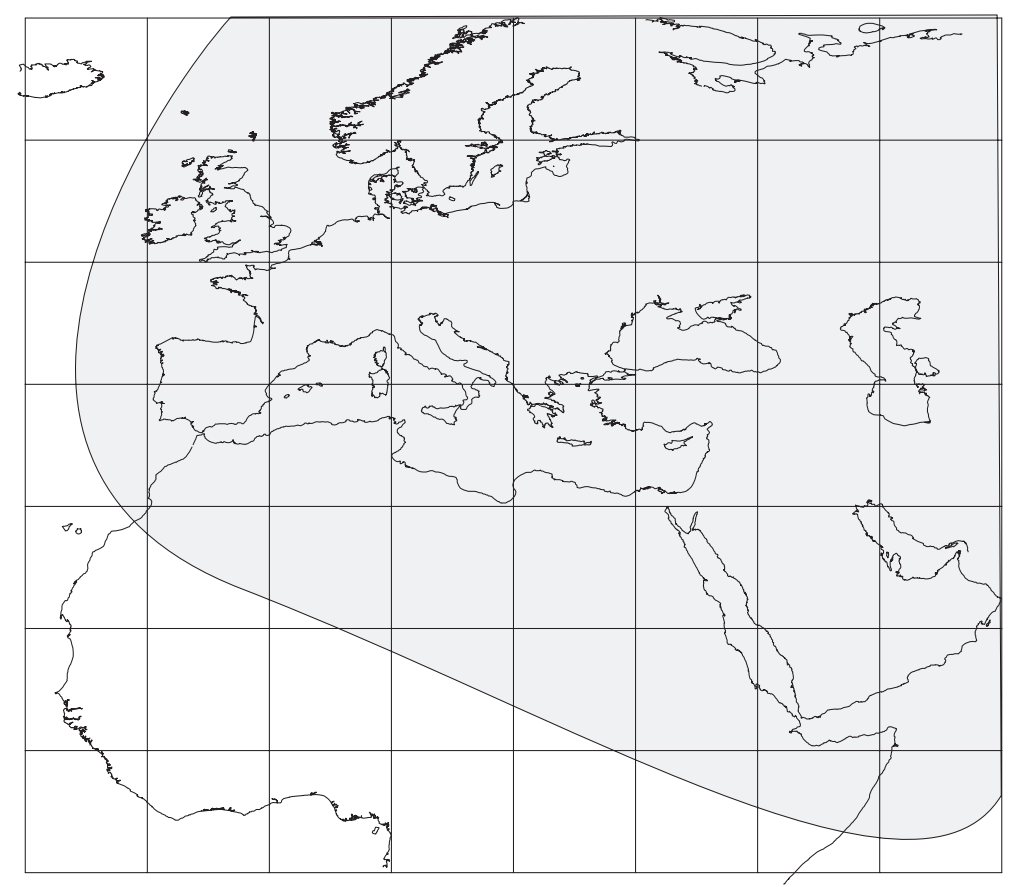

Fig. 1. Geographical domain considered in the present work (grey area). 


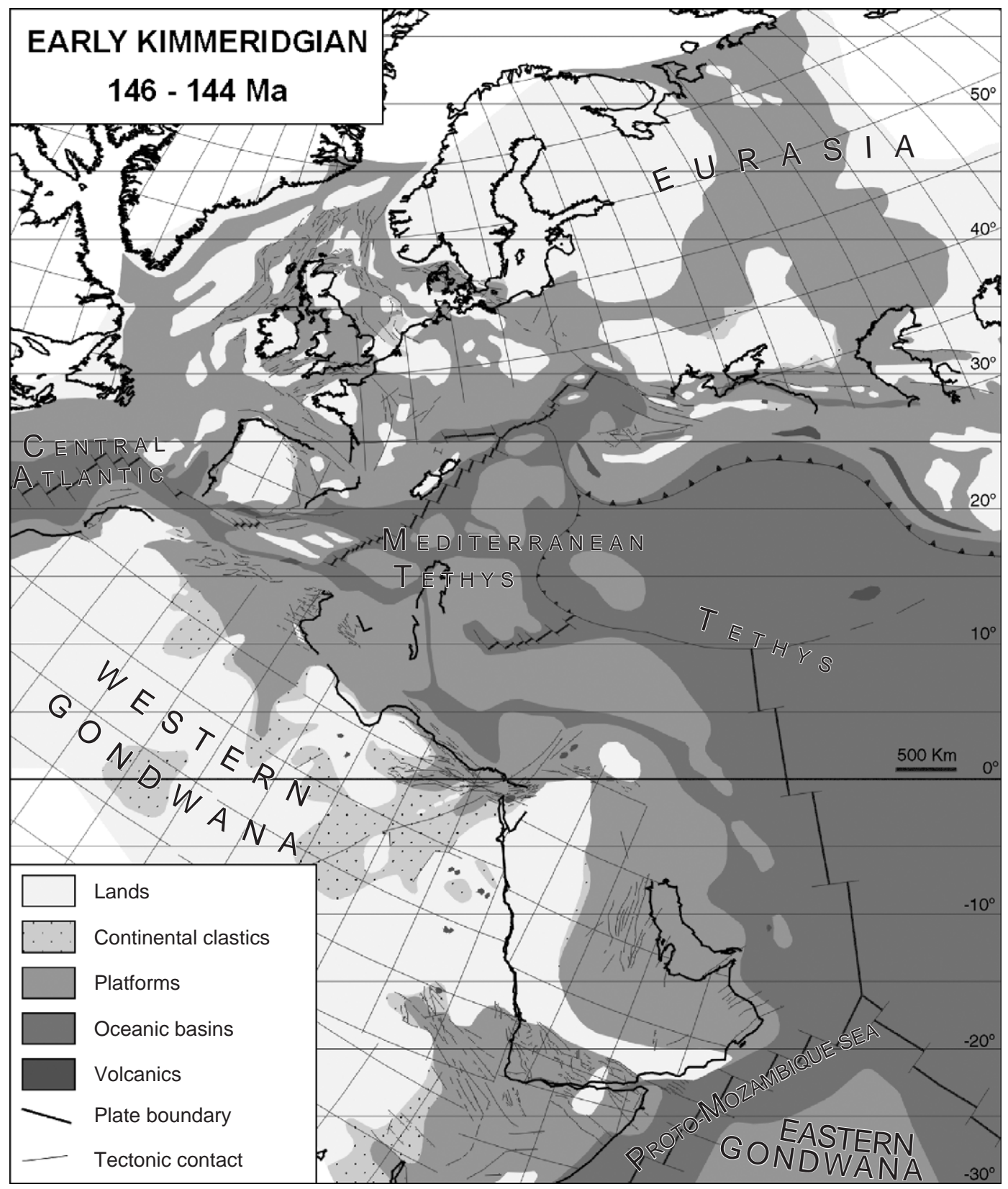

Fig. 2. Paleogeographic map of the early Kimmeridgian of the Tethyan and Peri-Tethyan areas (from Thierry, 2000, modified).

\subsection{Paleobiogeographical framework}

Two inclusive high rank biogeographic units are recognized: the Boreal Realm, in the high latitudes of the northern hemisphere, and the Tethyan Realm in low latitudes of both northern and southern hemi- spheres (Hallam, 1994; Cecca, 2002 and references therein). However, the limits of both Realms (and their constituent Provinces) fluctuated in response to eustatic, climatic and tectonic changes. In the cratonic seas of Central and Western Europe, well-documented range expansions and contractions of the two faunal 


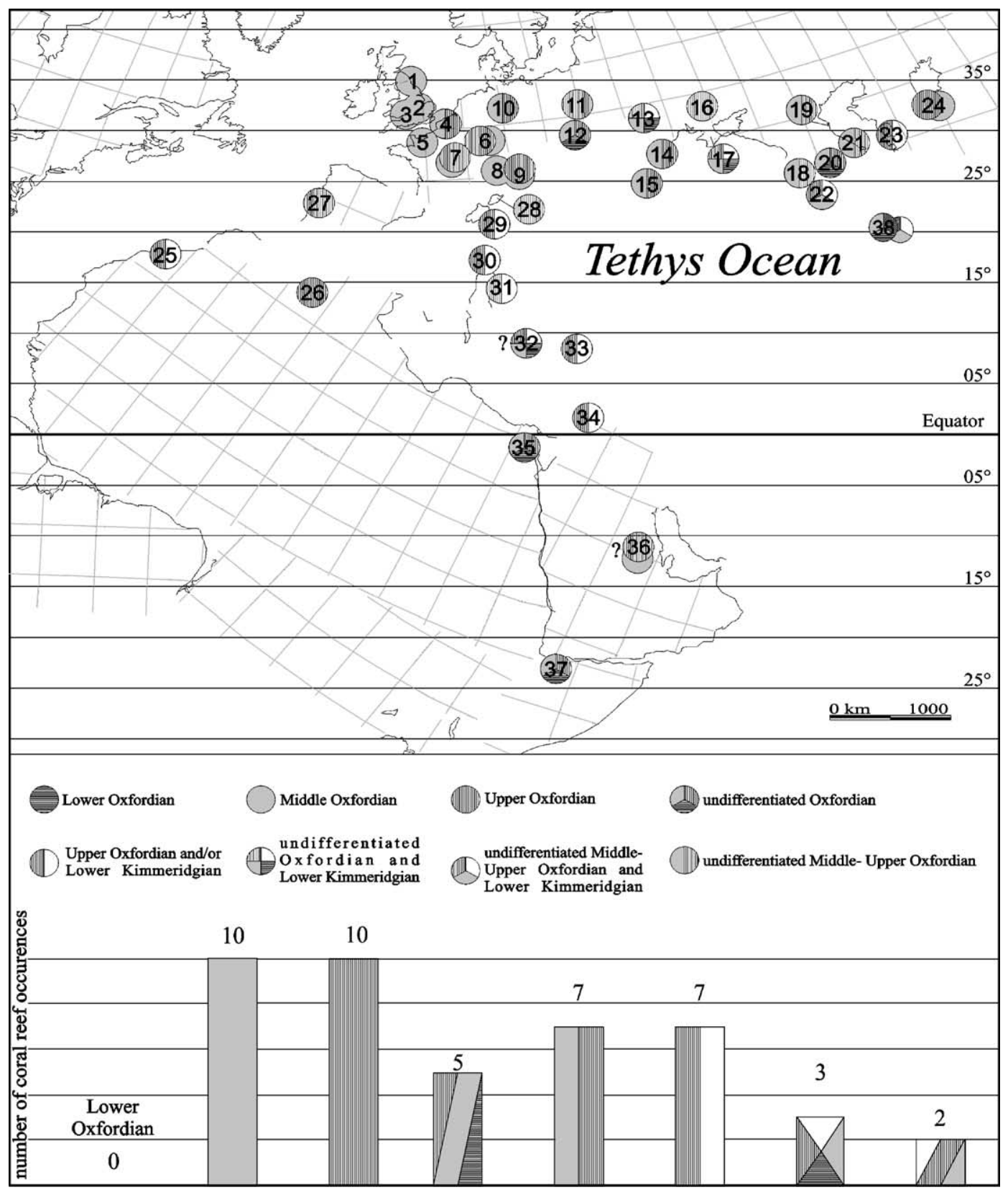

Fig. 3. Biogeographical and chronological distribution of coral reefs in the Oxfordian. The diagram below the map shows coral reef occurrences per substage or per time interval depending on uncertainties of age assignments. The paleogeographical positions of continental masses have been taken from the map of Thierry (2000). 1, England (Yorkshire); 2, England (Cambridgeshire); 3, England (Wiltshire and Oxfordshire); 4, France (Boulonnais); 5, France (Normandy); 6, France (Lorraine); 7, France (Burgundy); 8, France (North Jura); 9, Switzerland (Swiss Jura); 10, Germany (Hannover, Süntel Mountains); 11, Poland (Holy Cross Mountains); 12, Czech Republic (Brno); 13, Eastern Carpathian; 14, Moldavia; 15, Romania (Dobrogea); 16, Ukraine (Donetz); 17, Ukraine (Crimea); 18, Georgia (Abkhazia); 19, Northeast Caucasus; 20, North Ossetia; 21, Azerbaijan; 22, Armenia; 23, Turkmenistan; 24, Uzbekistan; 25, Morocco (Cap Ghir); 26, Algeria; 27, Portugal (Ota, Algarve); 28, France (Corsica; Caporalino); 29, Italy (Sardinia); 30, Italy (Friuli); 31, Slovenia; 32, Montenegro (Rumija); 33, Greece (Beotia); 34, Lebanon; 35, Egypt (Richet Umm Werib); 36, Saudi Arabia; 37, Somalia; Iran (Tabas). Data sources are reported in Table 1. 
Realms caused repeated shifts of biogeographical boundaries. These have been documented in detail for the Oxfordian (Enay, 1980; Enay and Mangold, 1982).

In both Realms, ammonite-based provinces can be distinguished. These are not easily matched with the distribution of coral reefs that is controlled by factors related to climatic conditions and sea level, but clearly help to illustrate biogeographical changes in the Oxfordian. The Sub-Boreal Province includes faunas that lived in areas now represented by southern England, north and northwestern France, northern Germany, northern Poland and Russia. Tethyan ammonites reached these areas in the Middle Oxfordian (Enay and Mangold, 1982). The Mediterranean Province was characterized by ammonites living in Mediterranean areas on the southern margin of Tethys plus those from the Subbetic Cordillera (in Southern Spain), which was on the northern margin. The SubMediterranean Province, recognized in localities on the northern margin of Tethys (the southern Eurasian platforms bordering the Mediterranean and Central Tethys), is identified by ammonite faunas displaying a lower diversity than those of the Mediterranean Province but characterized by repeated, brief sporadic arrivals of Boreal elements.

\section{Paleoclimate and paleotemperatures: available data}

\subsection{Climatic reconstructions based on GCM simulations}

A number of simulations of Late Jurassic climatic regimes have been made using contrasting GCM parameterizations (Moore et al., 1992a,b; Ross et al., 1992; Valdes and Sellwood, 1992; Sellwood and Valdes, 1997; Sellwood et al., 2000). Generally, average global temperatures for the Mesozoic Era have been regarded as higher than today. Sellwood and Valdes (1997) indicate that a warmer Earth would have been more humid, whereas during cooler phases it would have been drier and stressed the importance of cloud cover as a cause of the relative warmth at high latitudes in Mesozoic "greenhouse" type conditions. This seems to conflict with the widespread evidence of continental aridity during the Mesozoic
(Hallam, 1985), but different phases have been recognized (Price, 1999) and it is now recognized that the climate was not warm and equable over the entire Mesozoic.

The leading question is whether the climatic regimes depicted by these simulations stand the test of geological and biogeographical observations. There are no available GCM simulations available for the Oxfordian, those of Moore et al. (1992a,b), Ross et al. (1992), and Valdes and Sellwood (1992) refer to the Kimmeridgian-Tithonian, and those of Sellwood et al. (2000) only refer to the Kimmeridgian. It is difficult to find among these simulations for the Late Jurassic one that fits the conditions for the Early and Middle Oxfordian indicated by the geological record. In fact, most refer to a younger interval characterized by "greenhouse" conditions. By contrast, Dromart et al. (2003a) concluded, on the basis of geological, geochemical and paleontological evidence, that there was a severe Late Callovian-Early Oxfordian cooling, with continental ice formation for about 2.6 My. Our observations support this interpretation and additionally suggest warm and humid conditions in the middle Oxfordian.

\subsection{Long-term paleotemperature evolution as deduced from oxygen stable isotopes}

Most of the work on Jurassic oxygen isotopes has been on skeletal material from belemnites. Belemnite $\delta^{18} \mathrm{O}$ values show considerable scatter even from fossils from the same stratigraphical horizon and lacking overt evidence of diagenetic alteration. The scatter is probably due to vital effects and may relate to migration of the animals through the water column (Anderson et al., 1994). Nonetheless, reproducible long-term trends in $\delta^{18} \mathrm{O}$ are discernible. Long-term temperature changes inferred from $\delta^{18} \mathrm{O}$ values of belemnites from northern Germany, England, Scotland and Russia (paleolatitudes $30-45^{\circ} \mathrm{N}$ during the Late Jurassic) suggest a temperature minimum around the Callovian-Oxfordian boundary, and the onset of warm conditions in the Early Oxfordian (Podlaha et al., 1998; Riboulleau et al., 1998). The $\delta^{18} \mathrm{O}$ values of aragonite in molluscs from England and NW Poland show a similar pattern (Malchus and Steuber, 2002), with relatively low paleotemperatures during the Late Callovian-Early Oxfordian and higher values during 
the Late Oxfordian-Early Kimmeridgian (no data were presented for the Middle Oxfordian). These are consistent with palynological evidence from the southern North Sea region of a relatively low paleotemperature around the Callovian-Oxfordian boundary, followed by a distinct rapid warming in the basal part of the Middle Oxfordian (Abbink et al., 2001). Lécuyer et al. (2003) have shown that values of $\delta^{18} \mathrm{O}$ from shark teeth collected in localities of the Anglo-Paris Basin $\left(25^{\circ}\right.$ to $35^{\circ} \mathrm{N}$, Fig. 2) increase in the Late Callovian and remain high in the Early to Middle Oxfordian interval, suggesting low paleotemperatures in lower mid-latitudes. While these results may indeed reflect the expression of local conditions, they are based on analyses of teeth from taxa having different ecological requirements. The Late Callovian-Early Oxfordian data are mainly from teeth of Asteracanthus, while those for the Middle Oxfordian are from Sphenodus and pycnodontids (Dromart et al., 2003b). If only the $\delta^{18} \mathrm{O}$ values from Asteracanthus are selected, the low paleotemperature inferred for the Early Oxfordian would be followed by a warmer Late Oxfordian-Early Kimmeridgian period (no Asteracanthus data are available for the Middle Oxfordian) (Dromart et al., 2003a). Warming through the Oxfordian-Kimmeridgian interval has been suggested on the basis of oxygen isotopes from calcite and aragonite shells collected in mid- to high-paleolatitudes $\left(55-60^{\circ} \mathrm{S}\right.$, Falkand Plateau; $80^{\circ} \mathrm{S}$ New Zealand) (Price and Sellwood, 1997; Price and Gröcke, 2002; Gröcke et al., 2003). Brachiopod and belemnite values from central Poland (paleolatitude of $30-35^{\circ}$ ) indicate a temperature increase in the Middle and Late Oxfordian (Hoffman et al., 1991; Wierzbowski, 2002). A high resolution (ammonite subzone level) $\delta^{18} \mathrm{O}$ data set for the Oxfordian (Wierzbowski, 2004) showed that values from belemnites in mid-latitude Sub-Mediterranean and Boreal-Sub-Boreal provinces decrease from the Transversarium to the Planula zone, suggesting a paleotemperature increase. Oddly, the $\delta^{18} \mathrm{O}$ values from belemnites of the low latitude Mediterranean province hardly change from the Cordatum to Bifurcatus zone, with a negative shift only in the Bimammatum Zone. During the Bifurcatus zone $\delta^{18} \mathrm{O}$ values obtained from Mediterranean belemnites are heavier (indicating a colder paleotemperature) than those from sub-Mediterranean and boreal-sub-Boreal specimens (warmer paleotempera- ture). This apparent climatic paradox may be explained by differing life habits of the belemnites relative to depth (Wierzbowski, 2004) or by changes in the salinity. The $\delta^{18} \mathrm{O}$ values of biogenic carbonates are controlled by factors that include post-depositional isotopic exchange, seawater temperatures, "vital effect", and global and local variations in the isotopic composition of the seawater. In general, the ${ }^{18} \mathrm{O} /{ }^{16} \mathrm{O}$ ratio decreases in response to precipitation and/or runoff but is increased by evaporation. Hence, in high paleolatitudes $\delta^{18} \mathrm{O}$ derived values of paleotemperature may be biased by increased freshwater runoff and the semi-enclosed nature of the depositional basin (Price and Sellwood, 1997; Price and Gröcke, 2002; Gröcke et al., 2003). Conversely, in low latitudes arid conditions may have caused an increase in sea surface salinity, resulting in an apparent decrease of paleotemperature. The $\delta^{18} \mathrm{O}$ value is heavier by $0.25 \%$ o for each $1 \%$ increase in salinity, giving an apparent decrease in paleotemperature of apparent decrease of $1{ }^{\circ} \mathrm{C}$.

To conclude, the available $\delta^{18} \mathrm{O}$ data suggest cooling in the latest Callovian-earliest Oxfordian and the onset of a warming phase almost at the end of the Early Oxfordian, or from the Early-Middle Oxfordian, lasting throughout the Middle-Late Oxfordian. Local variations in salinity can be superimposed on this general warming trend and this may explain the paradox of apparently conflicting paleotemperatures derived from $\delta^{18} \mathrm{O}$ data from low and high paleolatitudes.

\section{Facies distribution during the Oxfordian}

In the paleogeographic domain studied, the Oxfordian interval is characterized by important facies changes in both space and time.

\subsection{Early Oxfordian}

In epioceanic areas of Tethys sedimentation in troughs or basins was characterized by radiolarites. By contrast, pelagic swell areas, here called Pelagic Carbonate Platforms (PCP) following Santantonio (1994), were typified by nodular, ammonite-rich condensed limestone sequences, the Rosso Ammonitico (Cecca et al., 1992). Lower Oxfordian deposits 
are rarely represented on PCP and hiatuses are common (Checa and Sequeiros, 1990). Intraoceanic platforms characteristically lack reefal facies carbonates (Bartolini et al., 1996 and references therein). In the southern part of the European platform (the Ardèche region in France, the Iberian chain in Spain, and Southern Poland) there is a gap in deposition of Upper Callovian-Lower Oxfordian, with a paraconformable contact of Middle Oxfordian strata on Middle Callovian (Brochwicz-Lewinski et al., 1984; Norris and Hallam, 1995). Extremely condensed and discontinuous carbonate deposits occur in France, in Poitou and Burgundy regions, and in the Swabian Alb, Southern Germany, the Early Oxfordian Mariae Zone lacks because of a gap, with shales of the Cordatum Zone resting paraconformably on nodular, discontinuous levels of the Late Callovian Lamberti Zone (Norris and Hallam, 1995). However, a thick shaly Lower Oxfordian succession, the "Terres Noires", is widespread in basin settings of southeastern France. In the Sub-Boreal Anglo-Paris Basin and in Boreal areas (East Greenland, Scotland, Siberia) the Lower Oxfordian is again represented by siliciclastic facies. These reflect a reduction in carbonate production in the Early Oxfordian (Budyko et al., 1987; Bartolini et al., 1996; Dromart et al., 1996, 2003a). Calculations of carbonate accumulation rates on both sub-tropical (Western Europe) and intertropical (Arabian block) carbonate platforms show very low values in the Callovian-Early Oxfordian time interval (Dromart et al., 2003b). On a global scale, the deposits of epeiric seas became almost carbonate free around the Callovian-Oxfordian transition. Nevertheless, there are few exceptions in the Upper Callovian shallow-water limestones of the Middle East (Hirsch et al., 1998) and Lower Oxfordian limestones of southern Poland and Iran (Fantini Sestini, 1968; Dromart et al., 2003b; Fürsich et al., 2003; Wilmsen et al., 2003). The apparent decrease in carbonate production persists in Mediterranean areas until the Late Oxfordian but carbonate recovery is seen in the Middle Oxfordian successions of the European cratonic platforms. The interpretation of the gaps and condensed sequences in England, France, Spain and Germany is controversial. Whereas Norris and Hallam (1995) and Hallam (2001) consider that these features suggest of a highstand in eustatic sea level Dromart et al. (2003b) envisage a sea-level fall, with an amplitude of at least several tens of metres in the Late Callovian.

\subsection{Middle Oxfordian}

Coral reefs are reported from the Transversarium Zone and to a lesser extent the Plicatilis Zone of numerous European countries. Carbonates are generally widespread starting from the Plicatilis Zone onwards, although greater accuracy is needed in the biostratigraphic time scale (Glowniak, 2000; Wierzbowski, 2002). Condensed sequences in the Transversarium Zone suggest transgressive conditions (Dromart et al., 2003b). A Middle Oxfordian peak optimum in radiolarite sedimentation was expressed in both the basins of Mediterranean Tethys and on PCPs, where radiolarites may be interbedded with Rosso Ammonitico (Baumgartner, 1987; Bartolini et al., 1996; Cecca et al., 2001). This relationship has been correlated with the well known positive shift of $\delta^{13} \mathrm{C}$ usually attributed to the Middle Oxfordian ammonite Transversarium Zone (Jenkyns, 1996; Weissert and Mohr, 1996; Wierzbowski, 2002) that follows the Plicatilis Zone, and is interpreted in the context of a greenhouse climate with a trend towards the eutrophication of oceanic waters (Bartolini et al., 1996, 1999; Cecca et al., 2001). These features are consistent with the lack of coral reefs on the Bahamian type intraoceanic carbonate platforms of Mediterranean Tethys (Fig. 3).

\subsection{Late Oxfordian}

During the Late Oxfordian, the southern margins of Mediterranean Tethys saw a general recovery of carbonate factories both on carbonate platforms and in pelagic basins (Bartolini et al., 1996). Rates of deposition of biogenic silica were low and radiolarian associations were characterized by reduced species diversity and by domination of dissolution-resistant taxa with a parallel trend in decreasing $\delta^{13} \mathrm{C}$ values (Bartolini et al., 1999). The fertility of surface waters and radiolarian production gradually decreased, allowing nannofossil communities to develop, but radiolarian preservation in sediments was still possible, probably due to the presence of silica-saturated pore waters in the sediment. A sponge megafacies that developed during the Middle Oxfordian is extensively 
represented along the southern margin of the European platform (Gaillard, 1983; Leinfelder, 2001; Wierzbowski, 2002) in relatively deep, neritic environments. Coral reefs are also reported in a wide range of latitudes from Sub-Boreal to Gondwanan areas: from $33^{\circ} \mathrm{N}$ to the equator for the northern hemisphere.

\section{Biogeography}

The biogeographical distributions of the fossil groups examined are based on a literature survey and new data in the case of coral reefs and on semiquantitative estimates of the relative abundance of Boreal invaders for ammonites.

\subsection{Distribution of coral reefs}

Coral reefs are part of a characteristic geoecological assemblage (Rosen, 1992) of carbonate platforms that allows warm shallow-water environments, generally limited to low latitudes, to be recognized. Due to the peculiar environmental requirements of most corals (light and nutrient availability, water temperature, salinity, and turbidity, see Harriott and Banks, 2002) their biogeographical distribution in space and time and the paleoecological characteristics of their assemblages are of major interest in the interpretation of paleoclimatic changes (Flügel et al., 1996; Kiessling, 2001).

Changes in the distribution of coral reef assemblages through time (expansion, contraction, disjunction or any other kind of distributional change) are interpreted as fossil signatures of the biotic response to perturbations or disruptions of environmental conditions. Rosen (1992) stressed that distributional change is only one of possible responses to loss of equilibrium. The organisms' endogenous processes may themselves accommodate, perhaps genetically, a certain amount of environmental change. In such a situation, the distributional area could remain the same. Other responses include speciation or extinction.

The paleobiogeographical distribution of supposed zooxanthellate corals in the Oxfordian is based on the data in Table 1 shown in Fig. 3 (see also Figs. 5-7). The paleolatitude values are deduced from the map of Thierry (2000) that is built on the paleolatitude grid of

Table 1

Sources of both biogeographic and chronostratigraphic data shown in Fig. 3

Middle Oxfordian

1 Yorkshire

2 Cambridgeshire

Negus, 1991; Insalaco, 1999;

Wright and Cox, 2001

Negus, 1991; Insalaco, 1999, Wright and Cox, 2001

3 Wilt- and Oxfordshire Negus and Beauvais, 1979; Negus, 1991; Insalaco, 1999; Wright and Cox, 2001

5 Normandy

6 Lorraine

Dugué et al., 1998

Beauvais, 1964; Geister and Lathuilière, 1991; Olivier et al., 2004; Lathuilière and Martin-Garin (personal unpublished data)

8 North Jura

9 Swiss Jura Beauvais, 1964; Habrant, 1998 Koby, 1880-1889; Beauvais, 1963, 1964; Pümpin, 1965; Dupraz, 1999; Dupraz and Strasser, 1999, 2002

24 Uzbekistan

36 Saudi Arabia

Late Oxfordian

6 Lorraine

7 Burgundy

9 Swiss Jura

10 Germany

11 Poland

16 Donetz

24 Uzbekistan

26 Algeria

27 Portugal

28 Corsica

36 Saudi Arabia

Undifferentiated Oxfordian

12 Czech Republic

20 North Ossetia

35 Egypt
Saidusmanov, 1974a,b; Khusanov, 1983, 1984b, 1987 El-Asa'ad, 1991

Beauvais, 1964; Geister and Lathuilière, 1991; Olivier et al., 2004; Bertling and Insalaco, 1998; Lathuilière and Martin-Garin (personal unpublished data)

Beauvais, 1964; Insalaco et al., 1997

Koby, 1880-1889; Beauvais,

1963; Beauvais, 1964;

Pümpin, 1965; Dupraz,

1999; Dupraz and Strasser,

1999, 2002

Bertling, 1993

Roniewicz, 1966

Krasnov et al., 1977;

Krasnov, 1983

Saidusmanov, 197a,b;

Khusanov, 1983, 1984b, 1987

Benest et al., 1998

Leinfelder, 1992; Bendukidze, 1982; Rosendahl, 1985

Beauvais and Rieuf, 1981

El-Asa'ad, 1991

Eliásová, 1994

Krasnov et al., 1977; Krasnov, 1983

Alloiteau and Farag, 1964 
Table 1 (continued)

Undifferentiated Oxfordian

37 Somalia Thomas, 1935

38 Iran Pandey and Fürsich, 2003

Undifferentiated Oxfordian and Early Kimmeridgian

13 Eastern Carpathian Krasnov et al., 1977; Krasnov, 1983

17 Crimea

Krasnov, 1964, 1965, 1983;

Ljuljeva and Permjakov,

1980; Bendukidze, 1982

32 Montenegro

Krkovic, 1965

38 Iran

Pandey and Fürsich, 2003

Undifferentiated Middle-Late Oxfordian

10 Germany Helm and Schülke, 1998, 2003; Helm et al., 2001,

2003a,b; Reuter et al., 2001

Undifferentiated Middle-Late Oxfordian and Early Kimmeridgian

22 Armenia

Papoyan, 1977, 1980

Late Oxfordian and/or Early Kimmeridgian

4 Boulonnais Schnyder et al., 2000

14 Moldavia Krasnov et al., 1977;

Krasnov, 1983

15 Romania Roniewicz, 1976

18 Georgia Bendukidze, 1977, 1982;

Krasnov et al., 1977;

Krasnov, 1983; Lebanidze, 1991

19 Northeast Caucasus Bendukidze, 1977; Krasnov

et al., 1977;

Krasnov, 1983; Bendukidze, 1982

21 Azerbaijan

23 Turkmenistan

25 Morocco

29 Sardinia

30 Italy

31 Slovenia

33 Greece

34 Lebanon

Babaev, 1970, 1973; Krasnov

et al., 1977; Bendukidze, 1982

Khusanov, 1984a, 1985

Ambroggi, 1963; Hüssner,

1985; Ourribane et al., 1999,

2000; Martin-Garin et al., 2004

Russo and Sirna, 1986

Insalaco et al., 1997

Turnsek, 1997

Beauvais, 1972

Felix, 1903

Besse and Courtillot (1991) and the kinematic parameters presented by Ricou (1994). Due to the difficulties of high-resolution dating of reefal rocks and of correlation with ammonite biozones, three substages of the Oxfordian have been plotted. Numerous uncertainties in age assignments are acknowledged. For example, Late Oxfordian and Early Kimmeridgian assemblages are difficult to differentiate. The accuracy in age assignments depends both on correlation and the geometrical relationships between the reefal

formations and ammonite-bearing heteropic strata. Absence of the latter strata severely limits, or precludes, accurate dating and hampers a sound, quantitative estimation of diversity fluctuations through time. Nevertheless, to the left of the lower part of Fig. 3, are tentative plots of numbers of coral reef occurrences per substage, when age assignments were sufficiently reliable. Numbers to the right represent coral reef occurrences at chronological intervals whose extent depends on the degree of uncertainty of age assignments.

The distribution of coral reefs throughout the Oxfordian (Flügel and Flügel-Kahler, 1992; MartinGarin et al., 2002) is limited to about $35^{\circ} \mathrm{N}$ (Negus, 1991; Insalaco et al., 1997; Insalaco, 1999), compatible with the present northern limits, where coral reefs occur around Iki Island (Japan) at $33^{\circ} 48^{\prime} \mathrm{N}$ (Yamano et al., 2001). However, the most southerly Oxfordian reef was close to $25^{\circ} \mathrm{S}$ (Thomas, 1935) and contrasts with the present $31^{\circ} 40^{\prime} \mathrm{S}$ of the Recent Lord Howe Island reef (Harriott et al., 1995).

The lower part of Fig. 3 indicates that there are no undoubted Early Oxfordian coral reefs represented in our data. By contrast, reefs were abundant in both the middle and the late Oxfordian. The apparent absence of Lower Oxfordian coral reefs is underlined by the seven occurrences plotted as "undifferentiated Middle-Upper Oxfordian", seven plotted as "Upper Oxfordian and/or Lower Kimmeridgian" and the two occurrences plotted as "undifferentiated MiddleUpper Oxfordian and Lower Kimmeridgian". Poor dating may affect this picture as many age assignments of reefal complexes in Eastern Europe and Central Asia need to be reassessed. Lower Oxfordian corallian outcrops have been described from Sinai (Alloiteau and Farag, 1964), although their real reefal character remains to be established. Of course, Lower Oxfordian reef materials may be represented among the five occurrences plotted as "undifferentiated Oxfordian" and/or the three plotted as "undifferentiated Oxfordian and Early Kimmeridgian", but Middle or Late Oxfordian ages for all these records are more likely. In conclusion, this rough assessment of our data strongly supports the absence of Lower Oxfordian coral reef formations in the area represented in Fig. 3 (see also Fig. 5). There may be an exception in corals from Crimea, but the stratigraphical and paleoecological status of these needs to be revised. For the moment no 
Early Oxfordian coral reefs have been demonstrated and we must assume that reefs were at least scarce in this interval of time.

The distribution of Middle Oxfordian reef corals is noteworthy as very few are present in low latitudes. They are absent from the intraoceanic platforms of the Mediterranean Tethys and from the southern Eurasian platforms on the northern margin of Tethys. Their apparent occurrences on the southern margin correspond to poorly dated assemblages. Thus, Middle Oxfordian reefal development was most important between latitudes 20 and $35^{\circ} \mathrm{N}$. Coral reefs were not distributed symmetrically north and south of the equator, between the Tropics of Cancer $\left(23^{\circ} 27^{\prime} \mathrm{N}\right)$ and Capricorn $\left(23^{\circ} 27^{\prime} \mathrm{S}\right)$ like in the Recent. Middle Oxfordian reef-coral assemblages have been intensively studied and accurately dated in Western Europe, and exhibit high diversity. Reefal development appears to have followed an ecological succession beginning with biostromes dominated by "lamellar" microsolenids, and replaced in time by highly diverse reefal constructions. The northernmost occurrence recorded is in Yorkshire, England (Negus, 1991; Insalaco et al., 1997; Insalaco, 1999). Assemblages in this are characterized by an abundance of Thamnasteria, Isastrea, Thecosmilia, Montlivaltia, Rhabdophyllia? and Microsolena (Martin-Garin and Lathuilière, unpublished data) that probably have a less stenothermal character than other genera as is shown by trends recorded in the Bajocian for the first three genera (Lathuilière, 2000). The occurrence of Enallocoenia callomoni, reported from Greenland by Beauvais (1977) and cited by numerous authors, is excluded from our compilation, as it is represented by only a small piece of a single massive, non-reefal and possibly non-zooxanthellate coral. The description of less northerly corals at Navidale (NE Scotland) refers to resedimented clasts found in Kimmeridgian deposits together with blocks of Devonian sandstones (Beauvais, 1977). Their presumed Middle Oxfordian age and their ecology remain dubious. The reefal character of outcrops at Rumija (Montenegro, Jugoslavia; Krkovic, 1965) and in Central Saudi Arabia (Hanifa Formation, Hawtah Member, El-Asa'ad, 1991) on the southern margin has not been clearly demonstrated. Upper Jurassic reefs were believed to occur in Madagascar. Kiessling et al. (1999) and Leinfelder et al. (2002) plotted a reef occurrence in
SW Madagascar on their paleogeographic maps inexplicably quoting Pichon (1972) and Beauvais (1985), whose papers refer respectively to Plioquaternary and Bathonian-Callovian outcrops. However, a paper by Mette (2004) indicates a rich coral fauna in the Middle/Upper Oxfordian interval of the Dangovato section, Morondava basin.

Because they lack sufficient age-diagnostic elements it is difficult to separate Upper Oxfordian reefal formations from those of the Lower Kimmeridgian. A Late Oxfordian recovery of coral reefs in low latitudes seems to have occurred on the intraoceanic platforms of the Mediterranean in Morocco, Algeria, and Lebanon; in these areas reefs span a latitudinal interval between $32^{\circ} \mathrm{N}$ and $10^{\circ} \mathrm{S}$. However, problems of age assignment mean that their recovery may have been completed in the early Kimmeridgian. In many instances the reefal character of these coral assemblages is clear. The northernmost occurrences are in northern Germany (Bertling, 1993; Helm and Schülke, 1998) but, Helm and Schülke (2003), Helm et al. (2001, 2003a,b) and Reuter et al. (2001) indicate that these may be Middle Oxfordian. Interestingly, the reefal assemblages typical of the Middle Oxfordian in northern latitudes are found at lower latitudes in the Upper Oxfordian of eastern France (Lorraine) and Switzerland (Martin-Garin et al., 2002).

In conclusion, fluctuations in the biogeographical distribution of coral reefs during the Oxfordian suggest a latitudinal shift of climatic belts. The cooling event that started in the Late Callovian (Podlaha et al., 1998; Riboulleau et al., 1998; Abbink et al., 2001; Malchus and Steuber, 2002; Dromart et al., 2003a,b) continued into the Early Oxfordian and is indicated by the absence of reefal formations in the geographical domain considered here. This climatic event also explains the hiatus recognized in Central Europe because cooling hampered carbonate production. The recovery of coral reefs in the Middle Oxfordian is limited to the European epicontinental platform in a narrow latitudinal belt between $25^{\circ}$ and $35^{\circ} \mathrm{N}$ (perhaps more). These reefal formations seem to indicate oligotrophic conditions at their climax stage, and hence scarce nutrient supply, suggesting an arid climate on the bordering landmass. No reef recovery is indicated for Mediterranean Tethys in this period (Fig. 3). The complete recovery of coral reefs 
throughout the whole geographic domain was in the Late Oxfordian. However, there are argillaceous intercalations in Upper Oxfordian European platform successions, and the reefal facies differ from those of the Middle Oxfordian and do not suggest oligotrophic conditions (Dupraz, 1999; Dupraz and Strasser, 2002; Carpentier et al., 2002; Olivier et al., 2004). The widespread occurrence of microbialites suggests mesotrophy and eutrophy, with arguably more nutrients and a local more humid climatic conditions in the Late Oxfordian (Pittet, 1996). At lower latitudes, in the Mediterranean Tethys, the low proportion of biogenic silica in sediments suggests dilution of radiolarites by peri-platform oozes. This is correlated with the recovery of high carbonate production on intraoceanic platforms.

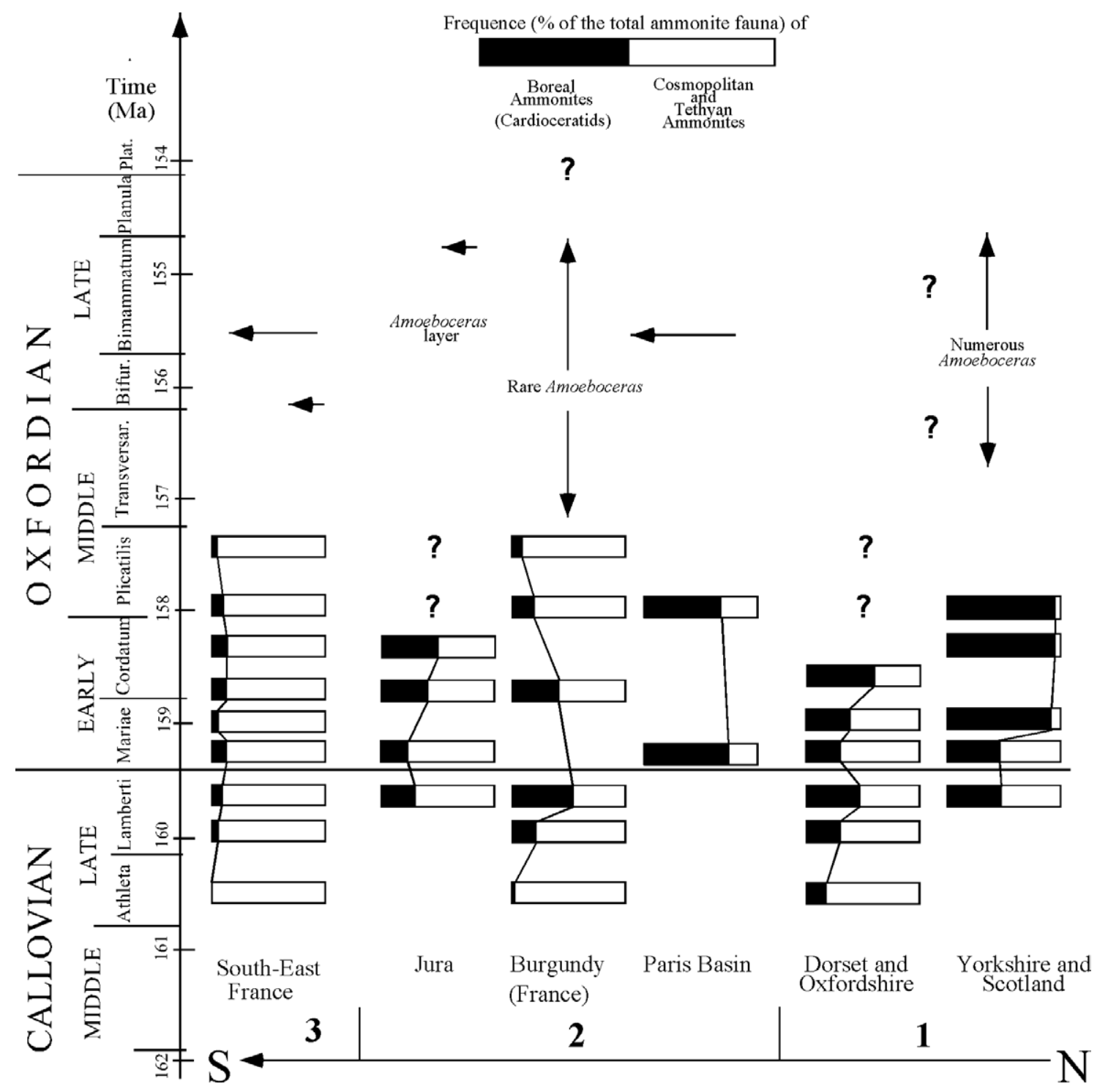

Fig. 4. Fluctuation in time of the frequence of representatives of the Boreal family Cardioceratidae within ammonite assemblages in three selected paleogeographical regions: (1) Scotland/Yorkshire and Oxfordshire/Dorset in England, (2) Paris Basin, Burgundy and Jura mountains in France, (3) Southeast France. Data have been taken from varied sources (see text). The ages assigned to ammonite zones are taken from Hardenbol et al. (1998). 


\subsection{Ammonites}

In the late Callovian, true boreal ammonites such as cardioceratids and kosmoceratids began to spread towards lower latitudes and to reach the southern margin of the European platform (the northern margin of the Tethys) although they never crossed this paleogeographical and paleoecological boundary (Enay, 1980; Enay and Mangold, 1982; Gygi and Marchand, 1982; Marchand, 1984, 1992; Cariou et al., 1985). Boreal ammonites consistently spread into southern France in the Late Callovian-Early Oxfor- dian, their movement coinciding with the absence of reefal formations. Thus, true Boreal ammonites (family Cardioceratidae) are present in Tethyan, Sub-Mediterranean, assemblages and have been as considered paleotemperature markers. Their southward expansion has been taken to suggest cooling (Dromart et al., 2003a).

There has so far been no precise analysis of the relative frequency, or temporal fluctuation, of representatives of the Cardioceratidae in either sub-Boreal or Sub-Mediterranean assemblages. This reflects a lack of data on numbers of specimens of each ammonite taxon

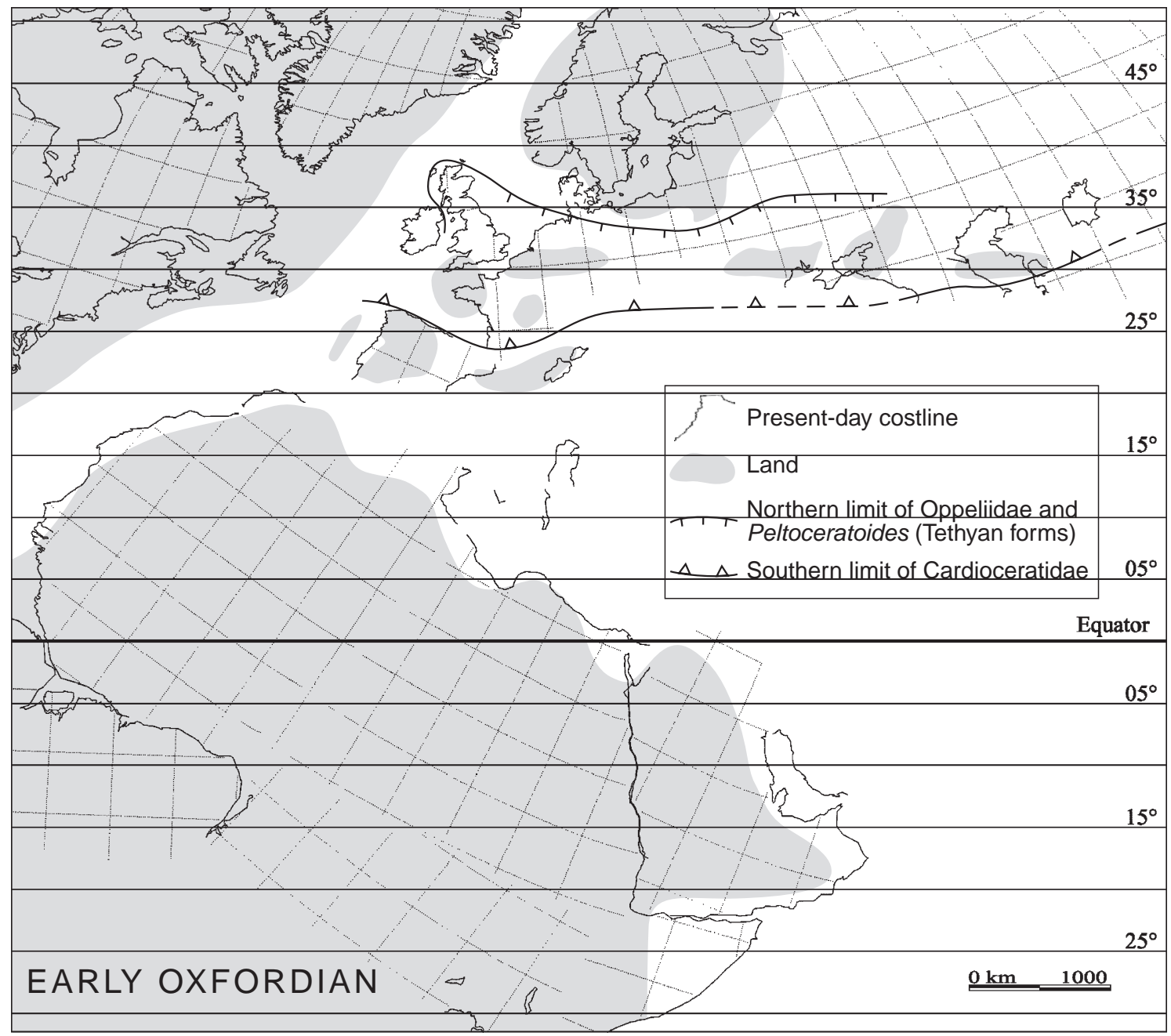

Fig. 5. Northern and southern limits of Tethyan (essentially Oppeliidae and Peltoceratoides) and Boreal ammonites respectively during the Early Oxfordian. The paleogeographical positions of continental masses have been taken from the map (Thierry, 2000, modified). Extent of land areas and biogeographical data have been taken from Enay and Mangold (1982) and (DM, FC) authors' personal data. 
collected at each locality. However, new data, and numbers of specimens noted in paleontological monographs provide rough estimates of the relative frequency of cardioceratids in assemblages along a northsouth transect (Fig. 4). This has only been possible for the interval from the Late Callovian Athleta zone to the Middle Oxfordian Plicatilis zone, as cardioceratids were only present sporadically during the rest of the Oxfordian. Three reference paleogeographical regions have been selected: (1) Scotland/Yorkshire and Oxfordshire/Dorset in England, (2) the Paris Basin, Burgundy and the Jura mountains in France, (3)
Southeast France. Data have been taken from different sources: Arkell (1948), Wright (1973, 1986, 1996a,b, 1997), Sykes and Callomon (1979), Vidier et al. (1993), Callomon (1985) and Marchand (1986) for Scotland/Yorkshire and Oxfordshire/Dorset; Enay (1966), Marchand and Dardeau (1979), Gygi and Marchand (1982), Marchand (1986), Dommergues and Marchand (1988) and Courville et al. (2000) for the Paris Basin, Burgundy and the Jura mountains; Bourseau (1977), Dardeau and Marchand (1981) and Fortwengler and Marchand (1994), Fortwengler et al. (1997) for Southeast France.

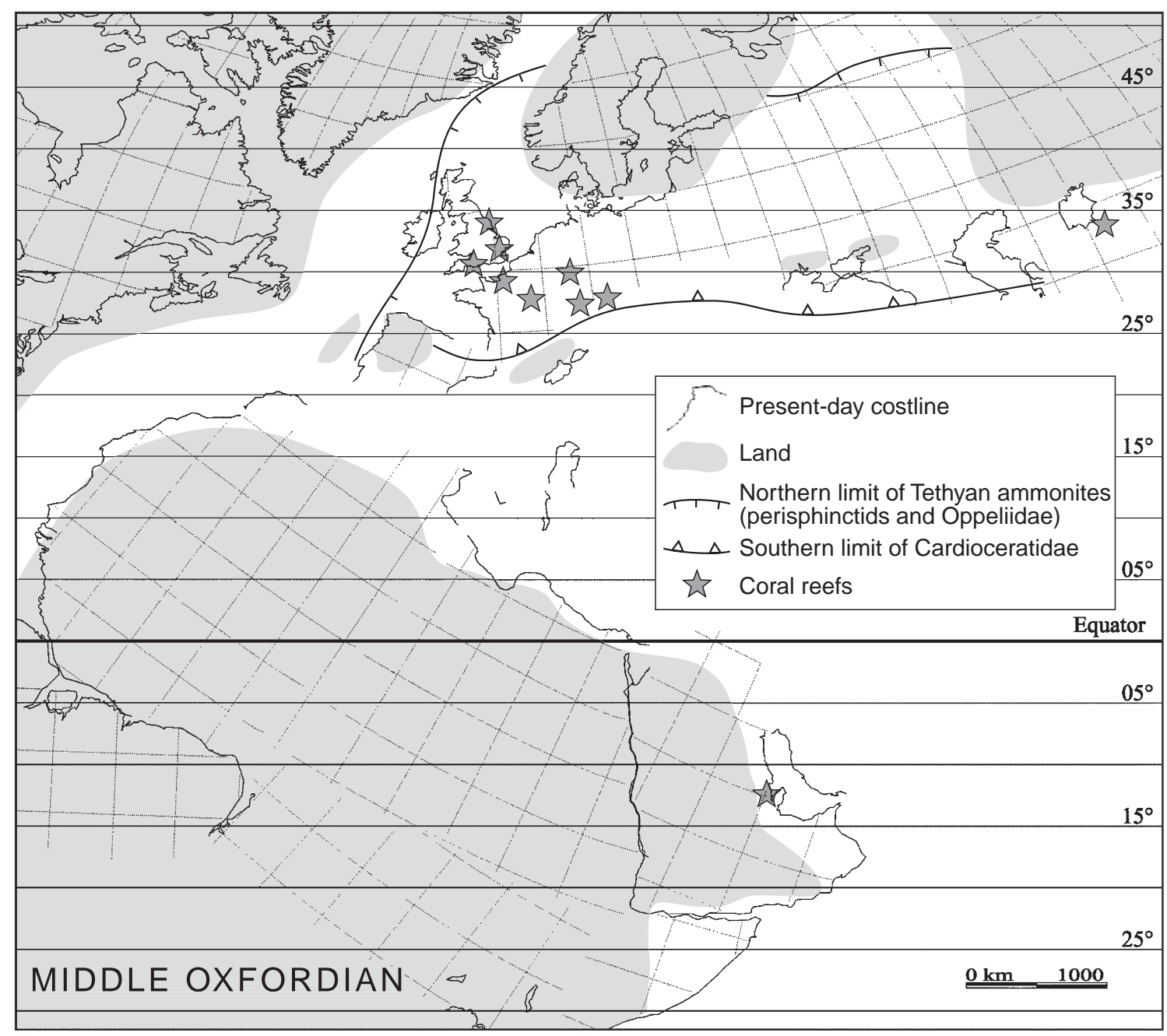

Fig. 6. Northern and southern limits of Tethyan and Boreal ammonites respectively during the Middle Oxfordian. The coral reef occurrences have been taken from the data presented in Fig. 3. Only the occurrences of unambiguous age assignment have been taken here. See also caption to Fig. 5. 
The arrival of Boreal ammonites in Sub-Mediterranean assemblages, indicated by both their relative frequency within the assemblages and the number of boreal species, occurred at the top of the Callovian from the Paris Basin to southern France. This faunal transgression (referred to as "unsuccessful recruitment" in Cecca, 2002) to the south continued into the Early Oxfordian (Fig. 4 and 5).

The Tethyan genus Peltoceratoides expanded its biogeographical range to the north (southern England, northern Germany), reaching Scotland during the Early Oxfordian (Cordatum Zone, Bukowski Subzone) (Marchand and Dardeau, 1979; Marchand,
1986). This does not conflict with the southward expansion of cardioceratids but simply reveals the eurythermal character of some Tethyan taxa (e.g. Peltoceratoides) and that northward extension had become possible (Fig. 5). This situation continued into the Early Oxfordian and in the Middle Oxfordian Plicatilis Zone, when other Tethyan ammonites reached Scotland (Fig. 6). However, in the Transversarium Zone there are fewer Boreal ammonites in the Paris Basin and they have almost disappeared in lower latitudes (Southeast France) (Fig. 4). In the Late Oxfordian deposits of this area only rare cardioceratids of the genus Amoeboceras are recorded (Atrops

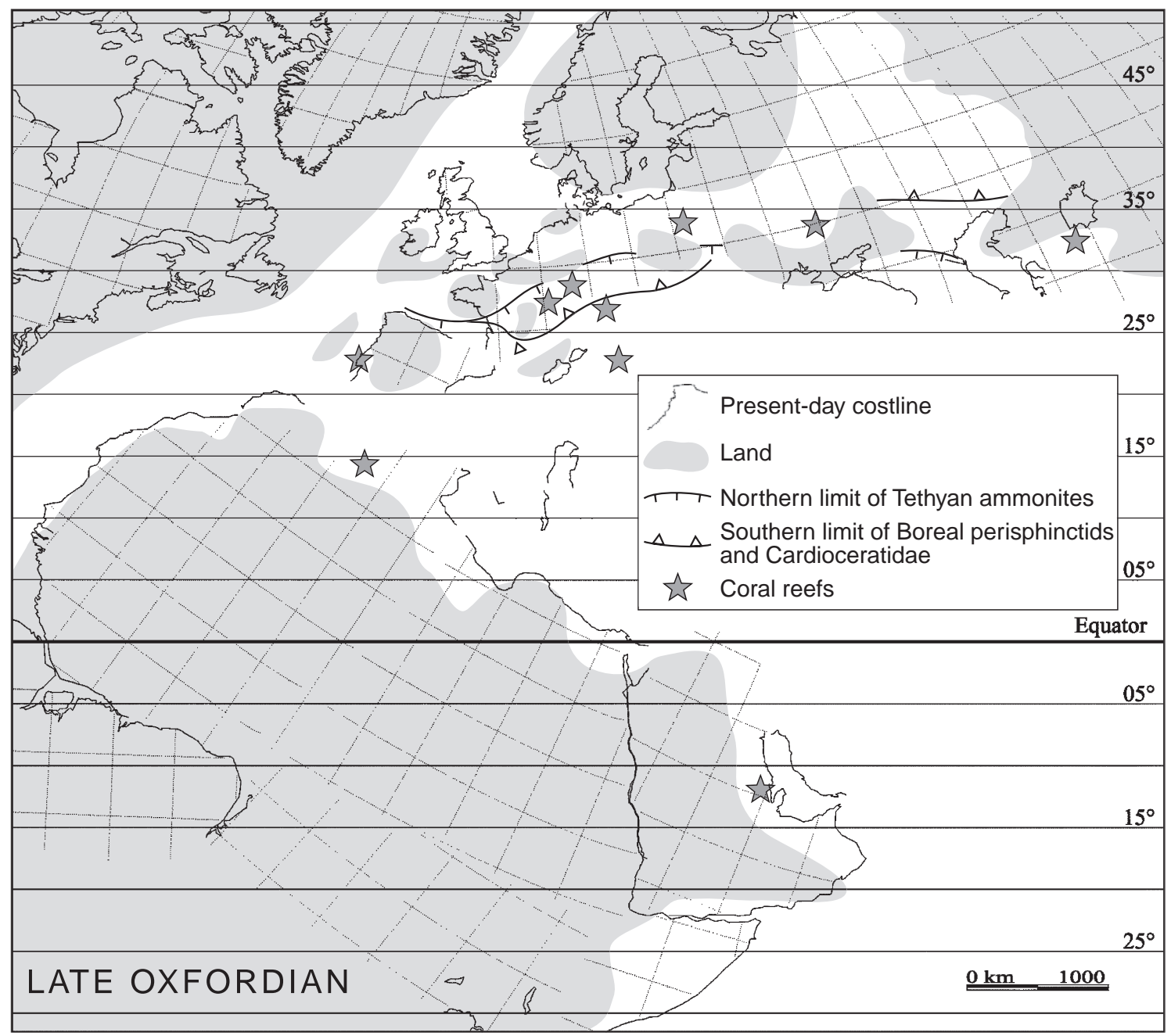

Fig. 7. Northern and southern limits of Tethyan and Boreal ammonites respectively, and coral reef occurrences during the Late Oxfordian. See also caption to Figs. 5 and 6. 
et al., 1993), whereas to the north, in Yorkshire and Scotland, Cardioceratidae continued to dominate ammonite assemblages (Wright, 1973, 1996b, 1997; Sykes and Callomon, 1979; Callomon, 1985) because the northern limit of Tethyan ammonites shifted southward (Fig. 7).

The interpretation of ammonite paleobiogeography in terms of paleoclimatic change is not straightforward as it strongly depends on sea-level changes that may have had a considerable impact on the distributional of marine faunas. The reconstruction of changes in sea level around the Callovian-Oxfordian boundary is controversial: Norris and Hallam (1995) recognized a transgression over western Europe; Jacquin et al. (1998) placed the top of a regressive cycle at the base of the Late Callovian Lamberti Zone and the top of the following transgressive cycle within the lower part of the Early Oxfordian Cordatum Zone; Dromart et al. (2003a,b) postulated an abrupt sea-level fall within the Lamberti Zone followed by a sea-level rise starting at the Callovian-Oxfordian boundary.

During a transgression "warm" Tethyan and "temperate" Boreal waters can be expected to mix. As a result, Tethyan and Boreal ammonite biotas should co-occur (as in southeastern France), with the southward expansion of the stenothermal forms (cardioceratids) and northward expansion of Tethyan eurytherms (for example Peltoceratoides). This scenario is consistent with the patterns described for the Early Oxfordian. However, morphological changes in cardioceratids of the Late Callovian-Middle Oxfordian (Gygi and Marchand, 1982; Marchand, 1986) may reflect adaptations to different environments and depth-habitats and require caution in drawing paleoclimatic conclusions.

\section{Paleoclimatic interpretation}

Our data demonstrate a number of expansions and contractions of bioprovinces. The temporal and spatial distribution of coral reefs, together with their facies characteristics, contrast with the wide distribution of radiolarites in Tethys but indicate that climatic conditions within the latitudinal belt considered were far from equable. At least three scenarios, roughly corresponding to Early, Middle and Late Oxfordian can be outlined.
The beginning of the Early Oxfordian was probably characterized by the persistence of cool conditions enhanced in the Late Callovian. A progressive warming in the Middle Oxfordian is demonstrated by a renewed growth of reefs and, with a lesser confidence, by ammonite biogeographical patterns. We interpret the lack of Lower Oxfordian reefal formations and the general absence of carbonates as the result of this cooling event, which lasted about 1 My (accepting the time scale used here). The widespread hiatus and the common absence of Upper Callovian and Lower Oxfordian deposits (Brochwicz-Lewinski et al., 1984) may be tentatively explained in terms of crises of carbonate production. This is consistent with the cooling hypothesis of Dromart et al. (2003a,b), who envisaged a sea-level fall in the Late Callovian followed by a sea-level rise starting around the Callovian-Oxfordian, boundary, but conflicts with the eustatic interpretation of Norris and Hallam (1995) and Hallam (2001) who considered that condensation due to transgression was a more plausible scenario. The ammonite biogeographical patterns for the Early Oxfordian are consistent with both eustatic interpretations. Personal observations and literature data show that around the Callovian-Oxfordian boundary real gaps are more common than condensations. In the basins of the northern margin of Tethys and in the small tectonic basins of the northeastern European platform, shaly successions accumulated during this interval and geochemical and palynological data confirm the cooling scenario outlined (Podlaha et al., 1998; Riboulleau et al., 1998; Collin, 2000; Abbink et al., 2001; Malchus and Steuber, 2002; Dromart et al., 2003a,b).

A warming event in the Middle Oxfordian leading to "greenhouse" type conditions is indicated by both biogeographical (mostly coral-reef distribution, see Fig. 3) and geochemical data (Hoffman et al., 1991; Jenkyns, 1996; Weissert and Mohr, 1996; Price and Sellwood, 1997; Cecca et al., 2001; Price and Gröcke, 2002; Gröcke et al., 2003; Wierzbowski, 2002, 2004). However, relatively arid conditions between 25 and $35^{\circ} \mathrm{N}$ (perhaps more) resulting in low run-off and depleted nutrient supply may account for the widespread development of reefal formations. In contrast, humid conditions, reflected in increased runoff and nutrient input are necessary to explain the maximum spread of radiolarites in the deep basins of the 
Mediterranean Tethys (Bartolini et al., 1996). This apparent contradiction may simply reflect climatic zones with contrasting precipitation regimes in the two latitudinal belts, connected with their positions relative to atmospheric cells. In this "greenhouse" period the fossil record implies contrasting regional climates. This interpretation is consistent with GCMs simulations and with the UGAMP model of Sellwood et al. (2000) in particular. An alternative, complementary, explanation links ocean currents and possible upwellings to the paleorelief of pelagic platforms (see map in Leinfelder, 1993, p. 20). No reefs were developed on Italian PCPs during the Jurassic. The Friuli carbonate platform (Insalaco et al., 1997) and the Umbria-Marche Apennines PCPs (Santantonio et al., 1997; Gill et al., 2004) are characterized by a significant microbial component and by pennular mesotrophic corals lacking a reef growth framework.

Distinct latitudinal belts are also inferred for the Late Oxfordian. During this period reefs extended between $10^{\circ} \mathrm{S}$ and $32^{\circ} \mathrm{N}$ (implying aridity or isolation) but further north biofacies analyses suggest humid conditions on the European platforms (Dupraz, 1999; Dupraz and Strasser, 1999, 2002; Carpentier et al., 2002). The difficulties of dating reefal formations limit knowledge of either the northward extent of the humid belt or the existence of relatively less humid conditions in Mediterranean areas. High resolution sequence stratigraphy coupled with cyclostratigraphy from sections in the Peri-Tethyan basins of western Europe (paleolatitude of $20-30^{\circ} \mathrm{N}$ ) show that during the Middle-Late Oxfordian, fluctuations and inversions of the high- and low-pressure atmospheric cells, driven by orbital insolation cycles, were superimposed on this general warming trend (Pittet and Strasser, 1998). The rainfall patterns and the distributions of corals, ooids, palynomorphs and siliciclastic sediments all followed the paleolatitudinal fluctuations of the atmospheric cells (Pittet and Strasser, 1998; Pittet et al., 2000). For example, during the Planula Zone, arid and oligotrophic conditions, and an important transgression, induced high carbonate production in the Jura Mountains and connected shallow platform areas (paleolatitude $26-27^{\circ} \mathrm{N}$ ), with large amounts of carbonate mud exported towards the deep shelf of southern Germany (Pittet et al., 2000). Contemporary data from the Prebetic Zone of southern Spain (paleolatitude $23-24^{\circ} \mathrm{N}$ ) suggest a more humid climate coupled with a dramatic decrease in carbonate deposition and condensed sedimentation allied to drowning of the platform (Pittet et al., 2000). The fluctuations of atmospheric cells may also have induced local variations in salinity, mirrored by excursions in the isotopic signal of the water mass (Bartolini et al., 2003; Wierzbowski, 2004).

The observed distribution of reefal facies during the Late Oxfordian-Early Kimmeridgian fits relatively well with the simulations of Sellwood et al. (2000): low rainfall in the Tethyan Mediterranean area (from 0.5 to $2.0 \mathrm{~mm}$ per day) and slightly higher rainfall (between 2.0 and $4.0 \mathrm{~mm}$ per day) in central and northern Europe. Unfortunately, detailed paleoecological studies of these peri-equatorial Oxfordian reefs are still lacking. A paleoclimatic model for the three epochs of the Oxfordian has yet to be realized taking into account paleotemperature values and paleogeographical maps with Oxfordian shorelines has yet to be established.

\section{Conclusions}

The cool climatic phase of the Late CallovianEarly Oxfordian proposed by Dromart et al. (2003a), and other potential cold phases reviewed by Price (1999), substantially weaken the old idea of a warmequable climate in the Jurassic. Our data confirm the extent of the cold episode in the Early Oxfordian but also suggest climate changes later in the Oxfordian. The geographical distribution of coral reefs (and less clearly of ammonites) together with facies distributions around the Tethyan margins suggest a possible "thermal maximum" in the Middle Oxfordian with general warm conditions persisting throughout the Late Oxfordian.

Changes in the biogeographical distribution of coral reefs provide a powerful tool for testing paleotemperature and paleoclimatic reconstructions based solely on geochemical markers.

The analyses of changes in biogeographical and facies distribution, related to $\delta^{18} \mathrm{O}$ variations, suggests paleolatitudinal patterns in precipitation regimes against a general background of a warm climate for the Middle and the Late Oxfordian. The consequent variations in salinity, linked to more arid or humid conditions, may bias the $\delta^{18} \mathrm{O}$ paleotemperature 
signal. The icehouse mode for at least for Middle and Late Oxfordian is not supported by biogeographic and facies data. There is a need for a more accurate time resolution of paleoclimatic changes.

Geological and paleontological data (Crowley and Berner, 2001) reconcile the tropical records of $\delta^{18} \mathrm{O}$ with the role of $\mathrm{CO}_{2}$ in long-term climate change and no longer can be overlooked in testing paleoclimatic models.

\section{Acknowledgements}

This paper has been realized in the framework of the project "Les effets du climat sur la biodiversité et les transferts sédimentaires au Jurassique et Crétacé" of the French CNRS "Eclipse I" Program. This study was also supported by the Swiss National Science Foundation (Grant 21-61834.00). We wish to thank our colleague Colin Braithwaite (University of Glasgow) who revised the English text and also provided useful suggestions. We also thank Alexandre Lethiers (UMR 5143, Paris) who has kindly realized the figures of this paper. A. Hallam, W. Kiessling and G.T. Moores, who acted as referees, provided criticism and valuable suggestions for the improvement of the manuscript.

\section{References}

Abbink, O., Targarona, J., Brinkhuis, H., Visscher, H., 2001. Late Jurassic to earliest Cretaceous palaeoclimatic evolution of the southern North Sea. Glob. Planet. Change 30, 231-256.

Alloiteau, J., Farag, I., 1964. Monographie des polypiers jurassiques d'Egypte. Bull. Inst. Egypte 39, 49-130.

Ambroggi, R., 1963. Etude géologique du versant méridional du Haut Atlas occidental et de la plaine de Sousse. Notes Mém. Serv. Géol. (Maroco) 157, 1-322.

Anderson, T.F., Popp, B.N., Williams, A.C., Ho, L.Z., Hudson, J.D., 1994. The stable isotope records of fossils from the Peterborough Member, Oxford Clay Formation (Jurassic), UK: palaeoenvironmental implications. J. Geol. Soc. (Lond.) 151, $125-138$.

Arkell, W.J., 1948. A monograph on the ammonites of the English Corallian Beds, Part 14. Palaeontogr. Soc. Lond. 102, $379-420$.

Atrops, F., Gygi, R.A., Matyja, B.A., Wierzbowski, A., 1993. The Amoeboceras faunas in the Middle Oxfordian-lowermost Kimmeridgian, Submediterranean succession, and their correlation value. Acta Geol. Pol. 43, 213-228.
Babaev, R.G., 1970. O nekotorykh ekologicheskikh osobennostyakh pozdneyurskikh skeleraktinij malogo Kavkaza (Azerbaydzhana). Mezozoyskie korally SSSR. Trudy II Vsesoyuznogo simposiuma po izucheniyu iskopaemykh korallov SSSR, vyp. 4, Akademiya Nauk SSSR, Akademiya Nauk estonskoj SSR, Institut geologii, Postoyannaya Kommissiya po izucheniyu iskopaemykh korallov SSSR, pp. 55-65 (in Russian).

Babaev, R.G., 1973. Pozdneyurskie chestilutchevye korally (skleraktinii) severo-vostochnoy chasti malogo Kavkaza (Azerbajdzhan). Akademiya Nauk Azerbaydzhanskoy SSR, Institut Geologii Imeni Akademika I.M. Gubkina (128 pp. (in Russian)).

Bartolini, A., Baumgartner, P.O., Hunziker, J.C., 1996. Middle and Late Jurassic carbon stable-isotope stratigraphy and radiolarite sedimentation of the Umbria-marche Basin (Central Italy). Eclogae geol. Helv. 89, 831-879.

Bartolini, A., Baumgartner, P.O., Guex, J., 1999. Middle and Late Jurassic radiolarian palaeoecology versus carbon-isotope stratigraphy. Palaeogeogr. Palaeoclimatol. Palaeoecol. 145, 43-60.

Bartolini, A., Pittet, B., Mattioli, E., Hunziker, J., 2003. Shallowplatform palaeoenvironmental conditions recorded in deep-shelf sediments: $\mathrm{C}$ and $\mathrm{O}$ stable isotopes in Upper Jurassic sections of southern Germany (Oxfordian-Kimmeridgian). Sediment. Geol. 160, 107-130.

Baumgartner, P., 1987. Age and genesis of Jurassic Radiolarites. Eclogae Geol. Helv. 80, 831-879.

Beauvais, L., 1963. Sur quelques genres de Madréporaires peu connus de 1'Argovien supérieur suisse. Bull. Soc. Géol. Fr. 5, $147-153$.

Beauvais, L., 1964. Etude stratigraphique et paléontologique des formations à madréporaires du jurassique supérieur du Jura et de l'est du Bassin de Paris. Mém. Soc. Géol. Fr. 100, 1-288.

Beauvais, L., 1972. Trois espèces nouvelles de Madréporaires de l'Oxfordien supérieur de Grèce continentale (Province de Boétie). Ann. Soc. Géol. Nord. 2, 95-98.

Beauvais, L., 1977. Une espèce nouvelle de madréporaire dans le Jurassique supérieur du Groenland et de l'Ecosse; implications paléogéographiques. Geobios 10, 135-141.

Beauvais, L., 1985. Les madréporaires jurassiques indicateurs de paléoenvironnements: quelques exemples. Palaeogeogr. Palaeoclimatol. Palaeoecol. 49, 207-215.

Beauvais, L., Rieuf, M., 1981. Découverte de Madréporaires oxfordiens dans les calcaires de Caporalino (Corse). Bull. Soc. Géol. Fr. 4, 353-359.

Bendukidze, N.S., 1977. Ecology of the Malm-Reef formation of the Great Caucasus. Mém. BRGM 89, 313-321.

Bendukidze, N.S., 1982. Pozdneyurskie korally rifogennikh otlozhenij Kavkasa i Kryma. Akademiya Nauk Gruzinskoj SSR, Geologicheskij Institut A.I. Dzhanelidze, Trudy, Novaja Serija Vyp, vol. 74. 220 pp. (in Russian).

Benest, M., Ouardas, T., Perriaux, J., Usuelle, J.P., 1998. Dynamique et contrôle de la sédimentation détritique de 1'Oxfordien supérieur au Kimméridgien supérieur (zone à Acanthicum) dans le cadre paléostructural de la plate-forme ouest algérienne. Bull. Serv. Géol. Algér. 9, 95-121. 
Berner, R.A., 1994. Geocarb II: a revised model of the atmospheric $\mathrm{CO}_{2}$ over Phanerozoic time. Am. J. Sci. 294, 56-91.

Bertling, M., 1993. Riffkorallen im Norddeutschen OberjuraTaxonomie, ökologie, Verteilung. Palaeontographica Abt. A 226, 77-123.

Bertling, M., Insalaco, E., 1998. Late Jurassic coral/microbial reefs from the northern Paris Basin-facies, palaeoecology and palaeobiogeography. Palaeogeogr. Palaeoclimatol. Palaeoecol. $139,139-175$.

Besse, J., Courtillot, V., 1991. Revised and synthetic apparent polar wander paths of the African, Eurasian, North American and Indian Plates, and true polar wander since 200 Ma. J. Geophys. Res. 96, 4029-4050.

Bourseau, J.P., 1977. L'Oxfordien moyen à nodules des “Terres noires" de Beauvoisin (Drôme): ammonitina de la zone à Plicatilis, paléontologie et biostratigraphie; milieu de sédimentation et genèse des nodules carbonatés. Nouv. Arch. Mus. Hist. Nat. Lyon 15, 1-116.

Brochwicz-Lewinski, W., Gasiewicz, A., Suffczynski, S., Szatkowski, K., Zbik, M., 1984. Lacunes et condensations à la limite Jurassique moyen-supérieur dans le Sud de la Pologne: manifestation d'un phénomène mondial? C. R. Acad. Sci. Paris 299 (II), 1359-1362.

Budyko, M.I., Ronov, A.B., Yanshin, A.L., 1987. History of the Earth's Atmosphere. Springer, Heidelberg. 139 pp.

Callomon, J.H., 1985. The evolution of the Jurassic ammonite family Cardioceratidae. Spec. Pap. Palaeontol. 33, 49-90.

Cariou, E., Contini, D., Dommergues, J.-L., Enay, R., Geyssant, J.R., Mangold, C., Thierry, J., 1985. Biogéographie des Ammonites et évolution structurale de la Téthys au cours du Jurassique. Bull. Soc. Géol. Fr., Sér. 8 I (5), 679-697.

Carpentier, C., Martin-Garin, B., Olivier, N., Lathuilière, B., Gaillard, C., Ferry, S., Hantzpergue, P., Geister, J., 2002. Succession des écosystèmes récifaux dans la carrière de Pagny-sur-Meuse (Lorraine): premières considérations sur l'évolution des environnements de dépôt au passage Oxfordien moyen-Oxfordien supérieur. Doc. Lab. Géol. Lyon 156, 65.

Cecca, F., 2002. Palaeobiogeography of Marine Fossil Invertebrates. Concepts and Methods. Taylor \& Francis, London. 271 pp.

Cecca, F., Fourcade, E., Azéma, J., 1992. The disappearance of the "Ammonitico Rosso". Palaeogeogr. Palaeoclimatol. Palaeoecol. 99, 55-70.

Cecca, F., Savary, B., Bartolini, A., Remane, J., Cordey, F., 2001. The Middle Jurassic-Lower Cretaceous Rosso Ammonitico succession of Monte Inici (Trapanese domain, Western Sicily): sedimentology, biostratigraphy and isotope stratigraphy. Bull. Soc. Géol. Fr. 172, 647-659.

Checa, A., Sequeiros, L., 1990. New data on the Lower Oxfordian from the Subbetic Zone (Betic Range, SE Spain). In: Meléndez, G. (Ed.), 1st Oxfordian Working Group Meeting, Zaragoza 1998, Publ. Sepaz., vol. 2, pp. 153-160.

Collin, P.-Y., 2000. Environnements, géochimie et processus de formation de séries condensées au Callovo-Oxfordien: du bassin de Paris à des considérations globales. Thèse Doct. Univ. Bourgogne. 282 pp.

Courville, P., Bonnot, A., Collin, P.-Y., Enay, R., Marchand, D., 2000. Une série oxfordienne de référence, à mi-chemin des régions boréales et téthysiennes (Jura Central, France). Rev. Paléobiol. Genève 19, 381-397.

Crowley, T.J., Berner, R.A., 2001. $\mathrm{CO}_{2}$ and climate change. Science 292, 870-872.

Dardeau, G., Marchand, D., 1981. Présence d'Amoeboceras newbridgense Sykes, ammonite boréale dans une faune mésogéenne de l'Oxfordien supérieur (zone à Bifurcatus) du S.E. de la France (Alpes-Maritimes): intérêt biostratigraphique, paléogéographique et paléobiogéographique. Geobios 14, $407-414$.

Dommergues, J.-L., Marchand, D., 1988. Paléobiogéographie historique et écologique: applications aux ammonites du Jurassique. In: Wiedmann, J., Kullmann, J. (Eds.), Cephalopods-Present and Past. Schweizerbart' sche Verlagsbuchhandlung, Stuttgart, pp. 351-364.

Dromart, G., Allemand, P., Garcia, J.-P., Robin, C., 1996. Variation cyclique de la production carbonatée au Jurassique le long d'un transect Bourgogne-Ardèche, Est-France. Bull. Soc. Géol. Fr. $167,423-433$.

Dromart, G., Garcia, J.-P., Picard, S., Atrops, F., Lecuyer, C., Sheppard, S.M.F., 2003a. Ice Age at the Middle-Late Jurassic transition? Earth Planet. Sci. Lett. 213, 205-220.

Dromart, G., Garcia, J.-P., Gaumet, F., Picard, S., Rousseau, M., Atrops, F., Lecuyer, C., Sheppard, S.M.F., 2003b. Perturbation of the carbon cycle at the Middle/Late Jurassic transition: geological and geochemical evidence. Am. J. Sci. 303, 667-707.

Dugué, O., Fily, G., Rioult, M., 1998. Le Jurassique des côtes du Calvados. Bull. Trimest. Soc. Géol. Normandie Amis Mus. Havre 2 (132 pp.)

Dupraz, C., 1999. Paléontologie, paléoécologie et évolution des faciès récifaux de l'Oxfordien Moyen-Supérieur (Jura suisse et français). PhD thesis, Univ. Fribourg, 1-200.

Dupraz, C., Strasser, A., 1999. Microbialites and Micro-encrusters in Shallow Coral Bioherms (Middle to Late Oxfordian, Swiss Jura Mountains). Facies 40, 101-130.

Dupraz, C., Strasser, A., 2002. Nutritional Modes in Coral-Microbialite Reefs (Jurassic, Oxfordian, Switzerland): evolution of trophic structure as a response to environmental change. Palaios 17, 449-471.

El-Asa'ad, G.M.A., 1991. Oxfordian hermatypic corals from central Saudi Arabia. Geobios 24, 267-287.

Eliásová, H., 1994. Scléractiniaires de Stránská skála (Oxfordien inférieur/supérieur, Brno, Moravie, République tchèque). Vẽstn. Ces. Geol. Úst. 4, 65-74.

Enay, R., 1966. L'Oxfordien dans la moitiée sud du Jura français. Etude stratigraphique. Nouv. Arch. Mus. Hist. Nat. Lyon, VIII, II, (Paléontol.), 1-300.

Enay, R., 1980. Paléobiogéographie et Ammonites jurassiques: "rythmes fauniques" et variations du niveau marin; voies d'échanges, migrations et domaines biogéographiques. Livre jubilaire de la Soc. géol. France, 1830-1980. Mém. Hors-Sér.Soc. Géol. Fr. 10, 261-281.

Enay, R., Mangold, C., 1982. Dynamique biogéographique et évolution des faunes d'Ammonites au Jurassique. Bull. Soc. Géol. Fr., Sér. 7 (24), 1025-1046.

Fantini Sestini, N., 1968. Lower Oxfordian ammonites from Dalichai Formation. Riv. Ital. Paleontol. Stratigr. 74, 403-418. 
Felix, J., 1903. Die Anthozoenfauna des Glandarienkalkes. I Teil, in Die fossile Fauna des libanesischen Jurakalkes. Beitr. Paläontol. Geol. österr.-Ung. Orients 15, 165-183.

Flügel, E., Flügel-Kahler, E., 1992. Phanerozoic reef evolution: basic questions and data base. Facies 26, 167-278.

Flügel, E., Kiessling, W., Golonka, J., 1996. Phanerozoic reef patterns: data survey, distribution maps and interpretation. In: Reitner, J., Neuweiler, F., Gunkel, F. (Eds.), Global and Regional Controls on Biogenic Sedimentation, Reef Sb2, pp. 391-396.

Fortwengler, D., Marchand, D., 1994. Nouvelles unités biochronologiques de la zone à Mariae. Geobios, Mém. H. Sér. 17, $203-209$.

Fortwengler, D., Marchand, D., Bonnot, A., 1997. Les coupes de Thuoux et de Savournon (SE de la France) et la limite Callovien-Oxfordien. Geobios 30, 519-540.

Fürsich, F.T., Wilmsen, M., Seyed-Emami, K., Schairer, G., Majidifard, M.R., 2003. Platform-Basin transect of a Middle to Late Jurassic large-scale carbonate platform system (Shotori Mountains, Tabas Area, East-Central Iran). Facies 48, 171-198.

Gaillard, C., 1983. Les biohermes à Spongiaires et leur environnement dans l'Oxfordien du Jura méridional. Doc. Lab. Géol. Lyon 90, 1-515.

Geister, J., Lathuilière, B., 1991. Jurassic coral reefs of the northeastern Paris Basin (Luxembourg and Lorraine). Fossil VI. Cnidaria. International Symposium on Fossil Cnidaria Including Archaeocyatha and Porifera, Münster (1991). International Association for the Study of Fossil Cnidaria and Porifera, Bern. 113 pp. Excursion Guidebook.

Gill, G.A., Santantonio, M., Lathuilière, B., 2004. The depth of pelagic deposits in the Tethyan Jurassic and the use of corals: an example from the Apennines. Sediment. Geol. $166,311-334$.

Glowniak, E., 2000. The Platysphinctes immigration event in the Middle Oxfordian of the Polish Jura Chain (Central Poland). Acta Geol. Pol. 50, 143-160.

Gradstein, F.M., Agterberg, F.P., Ogg, J.G., Hardenbol, J., van Veen, P., Thierry, J., Huang, Z., 1994. A Mesozoic time scale. J. Geophys. Res., B 99, 24051-24074.

Gradstein, F.M., Ogg, J.G., Smith, A.G., Bleeker 1, W., Lourens, L.J., 2004. A new geologic times table with special reference to Precambrien and Neogene. Episodes 27, 83-100.

Gröcke, D.R., Price, G.D., Ruffell, A.H., Mutterlose, J., Baraboshkin, E., 2003. Isotopic evidence for Late Jurassic-Early Cretaceous climate change. Palaeogeogr. Palaeoclimatol. Palaeoecol. 202, 97-118.

Gygi, R.A., Marchand, D., 1982. Les faunes de Cardioceratidae (Ammonoïdea) du Callovien terminal et de l'Oxfordien inférieur et moyen (Jurassique) de la Suisse septentrionale: stratigraphie, paléoécologie, taxonomie préliminaire. Geobios $15,517-545$.

Habrant, N., 1998. Zonation biologique et morphologie des coraux de l'Oxfordien de Bonnevaux-le-Prieuré (Jura, France), unpublished Diplôme d'Etudes Approfondies, Université de Lyon I, p. 44.

Hallam, A., 1985. A review of Mesozoic climates. J. Geol. Soc. (Lond.) 142, 433-445.
Hallam, A., 1994. An Outline of Phanerozoic Biogeography. Oxford Univ. Press. 246 pp.

Hallam, A., 2001. A review of the broad pattern of Jurassic sea-level changes and their possible causes in the light of current knowledge. Palaeogeogr. Palaeoclimatol. Palaeoecol. 167, 23-37.

Hardenbol, J., Thierry, J., Farley, M.B., Jacquin, T., De Graciansky, P.C., Vail, P.R., 1998. Mesozoic and Cenozoic sequence chronostratigraphic framework of European Basins. In: de Graciansky, P.C., Hardenbol, J., Jacquin, T., Vail, P.R. (Eds.), Mesozoic and Cenozoic Sequence Stratigraphy of European Basins, SEPM, Spec. Publ., vol. 60, pp. 3-13.

Harriott, V.J., Banks, S.A., 2002. Latitudinal variation in coral communities in eastern Australia: a qualitative biophysical model of factors regulating Coral reefs. Coral Reefs 21, 83-94.

Harriott, V.J., Harrison, P.L., Banks, S.A., 1995. The coral communities of Lord Howe Island. Mar. Freshw. Res. 46, 457-465.

Haug, E., 1908-1911. Traité De géologie, Partie 2: Les Périodes Géologiques. A. Colin éditeur, Paris, pp. 539-1396.

Helm, C., Schülke, I., 1998. A Coral-microbialite patch reef from the Late Jurassic (florigemma-Bank, Oxfordian) of NW Germany (Süntel Mountains). Facies 39, 75-104.

Helm, C., Schülke, I., 2003. Late Jurassic (Oxfordian) coral reefs of the Florigemma-Bank Member and Hainholz Member (Korallenoolith Formation, Lower Saxony Basin, NW Germany). Ber. Inst. Geol. Paläontol. Karl-Franzens Univ. Graz 7, 33.

Helm, C., Schülke, I., Fischer, R., 2001. Paläobiogeographie des Korallenooliths (Mittleres Oxfordium-Unteres Kimmeridgium): Tethyale Faunen- und Florenelemente auf höherer Paläobreite (Niedersöchsisches Becken, NW-Deutschland). Geol. Ber. Hann. 2, 51-64.

Helm, C., Reuter, M., Schülke, I., 2003a. Der Korallenoolith (Oberjura) im Osterwald (NW-Deutschland, Niedersöchsisches Becken): Fazielle Entwicklung und Ablagerungsdynamik. Z. Dtsch. Geol. Ges. 153, 159-186.

Helm, C., Reuter, M., Schülke, I., 2003b. Die Korallenfauna des Korallenooliths (Oxfordium, Oberjura, NW-Deutschland): Zusammensetzung, Stratigraphie und regionale Verbreitung. Paläontol. Z. 77, 77-94.

Hirsch, F., Bassoullet, J.P., Cariou, E., Conway, B., Feldman, H.R., Grosowicz, L., Honigstein, A., Owen, E.F., Rosenfeld, A., 1998. The Jurassic of the southern Levant. In: Crasquin-Soleau, S., Barrier, E. (Eds.), Epicratonic Basins of Peri-Tethyan Platforms. Mém. MNHN Paris 179, Peri-Tethys Memoir, vol. 4, pp. 213-235.

Hoffman, A., Gruszczynski, M., Malkowski, K., Halas, S., Matyja, B.A., Wierzbowski, A., 1991. Carbon and oxygen isotope curves for the Oxfordian of central Poland. Acta Geol. Pol. 43, $157-164$.

Hüssner, H., 1985. Jurassische Karbonate des westlichen Hohen Atlas (Marokko): mikrofaziesanalyse und plattentektonischer Rahmen. Facies 12, 141-218.

Insalaco, E., 1999. Facies and palaeoecology of Upper Jurassic (Middle Oxfordian) Coral reefs in England. Facies 40, 81-100.

Insalaco, E., Hallam, A., Rosen, B., 1997. Oxfordian (Upper Jurassic) coral reefs in western Europe: reef types and conceptual depositional model. Sedimentology 44, 707-734. 
Jacquin, T., Dardeau, G., Durlet, C., de Graciansky, P.C., Hantzpergue, P., 1998. The North-Sea cycle: an overview of 2nd order transgressive/regressive facies cycles in western Europe. In: de Graciansky, P.C., Hardenbol, J., Jacquin, T., Vail, P.R. (Eds.), Mesozoic and Cenozoic Sequence Stratigraphy of European Basins, SEPM, Spec. Publ., vol. 60, pp. 445-479.

Jenkyns, H.C., 1996. Relative sea-level change and carbon isotopes: data from the Upper Jurassic (Oxfordian) of central and Southern Europe. Terra Nova 8, 75-85.

Jenkyns, H.C., Jones, C.E., Gröcke, D.R., Hesselbo, S.P., Parkinson, D.N., 2002. Chemostratigraphy of the Jurassic System: applications, limitations and implications for paleoceanography. J. Geol. Soc. (Lond.) 159, 351-378.

Khusanov, S.T., 1983. Sistematicheskij sostav skeraktinij v rifakh Verkhnej Yury yuzhnogo i zapadnogo Uzbekistana. In: Leleshus, V.L. (Ed.), V Vsesoyuznyj simpozium po iskopaemym korallam i rifam, Tezisy DokladovAN SSSR Tadzhikskoj SSR, Dushanbe. 163 pp. (in Russian).

Khusanov, S.T., 1984a. Novye dannye o raspostranenii i stratigraficheskom znachenii pozdnejurskik chestiluchevykh korallov (skleraktinij) gaurdakskogo rifovogo massiva (yugo-zapadnyj Gissar). Uzb. Geol. Z. 1, 72-76 (in Russian).

Khusanov, S.T., 1984b. Stratigraficheskoe znachenie skleraktiniy karbonatnoj formacii verkhnej jury juziogo i zapadiogo Uzbekistana. Uzb. Geol. Z. Tashkent 6, 53-59 (in Russian).

Khusanov, S.T., 1985. Korally iz gaurdenskogo massiva (yugozapadnyj Gissar). Uzb. Geol. Z. 5, 62-66 (in Russian).

Khusanov, S.T., 1987. Pozdnejurskie skleraktinii rifogennykh otlozheniy juznogo i zapadnogo Uzbekistana. Ministerstvo Geologii Uzbekiskoj SSR, Institut Geologii i Razvedki Neftjanykh i Gazovykh Mestorozhdenij, vol. 108, pp. 1-90 (in Russian).

Kiessling, W., 2001. Paleoclimatic significance of Phanerozoic reefs. Geology 29, 751-754.

Kiessling, W., Flügel, E., Golonka, J., 1999. Paleoreef maps: evaluation of a comprehensive database on phanerozoic reefs. AAPG Bull. 83, 1552-1587.

Koby, F., 1880-1889. Monographie des polypiers jurassiques de la Suisse. Mém. Soc. Pal. Suisse vol. 7-16, 1-582.

Krasnov, E.V., 1964. Stratigraficheskoe znachenie verkhneyurskikh chestiluchevykh korallov Kryma. Bûll. Mosk. M.O.RA. Ispyt. Prir., Otd. Geol. 2, 85-89 (in Russian).

Krasnov, E.V., 1965. Novye dannye o raspostranenii i stratigraficheskom znachenii mal'mskikh rifovykh korallov Karpat, Preddobrudzhinskogo Progiba i Kryma. Karpato-Balkanskaya geologicheskaya Associaciya, VII Kongress Sofiya, 1965. Doklady, chast II, vol. 2, pp. 43-46 (in Russian).

Krasnov, E.V., 1983. Korally v rifovykh facijakh mezozoya SSSR. Akademiya Nauk SSSR Dal'nevostochij Nautchnyj Tsentr Dal'nevostochniyj Geologicheskij Institut, Moskva. (160 pp. in Russian).

Krasnov, E.V., Babaev, R.G., Bendukidze, N.S., Starostina, E.A., 1977. Rasprostranenie i ekologicheskaya differenciyaciya yurskikh madreporovykh korallov na territorii SSSR. Sreda i zhizn' v geologicheskom proshlom (Facii i organizmy) Sibirskoe otd, Akademii Nauka Novosibirsk, vol. 302, pp. 149-160 (in Russian).
Krkovic, D., 1965. Koralska Fauna sa Severnih Padina Planine Rumije (Crna Gora). Bull. Géol. Inst. Géol. Monten. 4, $155-182$.

Lathuilière, B., 2000. Coraux constructeurs du Bajocien inférieur de France, $1^{\text {ière }}$ et $2^{\text {ième }}$ parties. Geobios $33,51-72,153-181$.

Lebanidze, Z.M., 1991. Pozdnejurskie korally zapadnoj gruzii (Abkhaziya). Akademiya Nauk Gruzii, Geologicheskij Institut N.M.A.I. Dzanelidze, Trudy, Novaja Serija, Vyp, vol. 105, pp. 1-63 (in Russian).

Lécuyer, C., Picard, S., Garcia, J.-P., Sheppard, S.M.F., Grandjean, P., Dromart, G., 2003. Thermal evolution of Tethyan surface waters during the Middle-Late Jurassic: evidence from $\delta^{18} \mathrm{O}$ values of marine fish teeth. Palaeoceanography 18.

Leinfelder, R.R., 1992. A modern type Kimmeridgian reef (Ota limestone, Portugal): implications for Jurassic reef models. Facies 26, 11-34.

Leinfelder, R.R., 1993. Upper Jurassic reef types and controlling factors. A preliminary report. Profil 5, 1-45.

Leinfelder, R.R., 2001. Jurassic reef ecosystems. In: Stanley Jr., G.D. (Ed.), The History and Sedimentology of Ancient Reef Systems. Kluwer Academic/Plenum Publishers, New York, pp. 251-309.

Leinfelder, R.R., Schmid, D.U., Nose, M., Werner, W., 2002. Jurassic reef patterns the expression of a changing globe. SEPM Spec. Publ. 72, 465-520.

Ljuljeva, S.A., Permjakov, V.V., 1980. Kokkolitoforidy i korally mezozoya ukrainiy. Paleontologicheskij spravochnik. Akademiya Nauk Ukrainskoj SSR, Institut Geologicheskikh Nauk. 170 pp. (in Russian).

Malchus, N., Steuber, T., 2002. Stable isotope records (O, C) of Jurassic aragonitic shells from England and NW Poland: palaeoecologic and environmental implications. Geobios 35, 29-39.

Marchand, D., 1984. Ammonites et paléoenvironnements: une nouvelle approche. Geobios, Mém. Spéc. 8, 101-107.

Marchand, D., 1986. L'évolution des Cardioceratinae d'Europe occidentale dans leur contexte paléobiogéographique (Callovien supérieur-Oxfordien moyen). Thèse Doct. Etat Univ. Bourgogne, Dijon. 606 pp.

Marchand, D., 1992. Ammonites et paléoprofondeur: les faits, les interprétations. Paleovox 1, 49-68.

Marchand, D., Dardeau, G., 1979. Colonisations faunistiques dans l'Oxfordien inférieur d'Europe occidentale. Exemple pris chez les Ammonoïdés. 7ème R.A.S.T, Lyon, p. 311.

Martin-Garin, B., Lathuilière, B., Geister, J., 2002. Récifs, Coraux et Climats Oxfordiens de la Tethys. Doc. Lab. Géol. Lyon 156, $154-155$.

Martin-Garin, B., Lathuilière, B., Geister, J., Chellai, E.H., Huault, V., Ourribane, M., 2004. Les associations coralliennes du Jurassique supérieur, une clef de lecture pour la géologie des récifs: Exemple du Cap Ghir, Haut-Atlas Atlantique, Maroc. Deuxième Colloque sur le Jurassique Marocain. Université Cadi Ayyad, Marrakech, Morocco, pp. 76-77.

Mette, W., 2004. Middle to Upper Jurassic sedimentary sequences and marine biota of the early Indian Ocean (Southwest Madagascar): some biostratigraphic, paleoecologic and palaeobiogeographic conclusions. J. Afr. Sci. 38, 331-342. 
Moore, G.T., Hayashida, D.N., Ross, C.A., Jacobson, S.R., 1992a. Paleoclimate of the Kimmeridgian/Tithonian (Late Jurassic) world: I. Results using a general circulation model. Palaeogeogr. Palaeoclimatol. Palaeoecol. 93, 113-150.

Moore, G.T., Sloan, L.C., Hayashida, D.N., Umaigar, N.P., $1992 b$. Paleoclimate of the Kimmeridgian/Tithonian (Late Jurassic) world: II. Sensitivity tests comparing three different paleotopographic settings. Palaeogeogr. Palaeoclimatol. Palaeoecol. 95, $229-252$.

Negus, P.E., 1991. Stratigraphical table of scleractinian coral genera and species occurring in the British Jurassic. Proc. Geol. Assoc. $102,251-259$.

Negus, P.E., Beauvais, L., 1979. The corals of Steeple Ashton (English Upper Oxfordian), Wiltshire. Proc. Geol. Assoc. 90, 213-227.

Norris, M.S., Hallam, A., 1995. Facies variations across the Middle-Upper Jurassic boundary in Western Europe and the relationship to sea-level changes. Palaeogeogr. Palaeoclimatol. Palaeoecol. 116, 189-245.

Olivier, N., Carpentier, C., Martin-Garin, B., Lathuilière, B., Gaillard, C., Ferry, S., Hantzpergue, P., Geister, J., 2004. Coral-microbialite reefs in pure carbonate versus mixed carbonate-siliciclastic depositional environments: the example of the Pagny-sur-Meuse section (Upper Jurassic, Northeastern France). Facies 50, 229-255.

Ourribane, M., Chellai, E.H., Ezaidi, A., Içame, N., 1999. Un complexe récifal à stromatoporidés, coraux et microbialites: exemple du Kimméridgien de Cap-Guir (Haut-Atlas atlantique, Maroc). Géol. Méditerr. 26, 79-88.

Ourribane, M., Chellai, E.H., Zaghbib-Turki, D., 2000. Rôle des microbialites et des "micro-encroûtants" dans la lithification récifale: exemples du Jurassique supérieur de l'Atlas maghrébin (Maroc et Tunisie). C. R. Acad. Sci. Paris, Sci. Terre Planètes 330, 407-414.

Padden, M., Weissert, H., de Rafelis, M., 2001. Evidence for Late Jurassic release of methane from gas hydrate. Geology 29, $223-226$.

Pandey, D.K., Fürsich, F.T., 2003. Jurassic corals of east-central Iran. Beringeria 32, 3-138.

Papoyan, A.S., 1977. Korally iz otlozhenij Oksforda-Kimeridzha shamshadinskogo rajona. Izv. Akad. Nauk Arm. SSR, Nauki Zemle 6, 162-166 (in Russian).

Papoyan, A.S., 1980. Novye dannye o yurskikh korallakh severnoj chasti armyanskoj SSR. Korally i rify fanerozoya SSSR (Trudy IV Vsesoyuznogo simpoziuma po iskopaemym korallam, Tbilisi, 1978), pp. 162-166 (in Russian).

Pichon, M., 1972. Les peuplements à base de scléractiniaires dans les récifs coralliens de la Baie de Tuléar (sud-ouest de Madacasgar). First Internat. Symp. Corals and Coral Reefs, pp. 135-154.

Pittet, B., 1996. Contrôles climatiques, eustatiques et tectoniques sur des systèmes mixtes carbonates-siliciclastiques de plateforme: exemples de l'Oxfordien (Jura suisse, Normandie, Espagne). Thèse Univ. Fribourg 1124. 258 pp.

Pittet, B., Strasser, A., 1998. Long-distance correlations by sequence stratigraphy and cyclostratigraphy: examples and implications (Oxfordian from the Swiss Jura, Spain, and Normandy). Geol. Rundsch. 86, 852-874.
Pittet, B., Strasser, A., Mattioli, E., 2000. Depositional sequences in deep-shelf environments: a response to sea-level changes and shallow-platform carbonate productivity (Oxfordian, Germany and Spain). J. Sediment. Res. 70, 392-407.

Podlaha, O.G., Mutterlose, J., Veizer, J., 1998. Preservation of $\delta^{18} \mathrm{O}$ and $\delta^{13} \mathrm{C}$ in belemnite rostra from the Jurassic/early Cretaceous successions. Am. J. Sci. 298, 324-347.

Price, G., 1999. The evidence of Polar ice during the Mesozoic. Earth-Sci. Rev. 48, 183-210.

Price, G., Gröcke, D.R., 2002. Strontium-isotope stratigraphy and oxygen- and carbon-isotope variation during the Middle Jurassic-Early Cretaceous of the Falkland Plateau, South Atlantic. Palaeogeogr. Palaeoclimatol. Palaeoecol. 183, 209-222.

Price, G., Sellwood, B.W., 1997. "Warm" palaeotemperatures from high Late Jurassic palaeolatitudes (Falkland Plateau): ecological, environmental or diagenetic controls? Palaeogeogr. Palaeoclimatol. Palaeoecol. 129, 315-327.

Pümpin, V.F., 1965. Riffsedimentologische Untersuchungen im Rauracien von St. Ursanne and Umgebung (Zentraler Schweizer Jura). Eclogae geol. Helv. 2, 799-879.

Reuter, M., Fischer, R., Helm, C., Schülke, I., 2001. Entwicklung und Faziesverteilung eines Riffkomplexes im Korallenoolith (Oberjura) des Osterwaldes (Niedersachsen). Geol. Ber. Hann. $2,31-50$.

Riboulleau, A., Baudin, F., Daux, V., Hantzpergue, P., Renard, M., Zakharov, V., 1998. Evolution de la paléotempérature des eaux de la plate-forme russe au cours du Jurassique supérieur. C. R. Acad. Sci. Paris, Sci. Terre Planètes 326, 239-246.

Ricou, L.-E., 1994. Tethys reconstructed: plates, continental fragments and their Boundaries since 260 Ma from Central America to South-eastern Asia. Geodin. Acta 7, 169-218.

Roniewicz, E., 1966. Les madréporaires du Jurassique supérieur de la bordure des Monts de Sainte-Croix, Pologne. Acta Palaeontol. Pol. 11, 157-264.

Roniewicz, E., 1976. Les scléractiniaires du Jurassique supérieur de la Dobrogea Centrale (Roumanie). Palaeontol. Pol. 34, 1-121.

Rosen, B.R., 1992. Empiricism and the biogeographical black box: concepts and methods in marine palaeobiogeography. Palaeogeogr. Palaeoclimatol. Palaeoecol. 92, 171-205.

Rosendahl, S., 1985. Die oberjurassische Korallenfazies von Algarve (Südportugal). Arb. Inst. Geol. Univ. Stuttg., N. F. 82, 1-125.

Ross, C.A., Moore, G.T., Hayashida, D.N., 1992. Late Jurassic paleoclimate simulation-paleoecological implications for Ammonoid provinciality. Palaios 7, 487-507.

Russo, A., Sirna, G., 1986. Nota preliminare sul Malm di Cala Gonone (Golfo di Orosei, Sardegna). Geol. Rom. 25, 165-180.

Saidusmanov, U., 1974. Stratigraficheskoe polozenie pozdieoksfordkikh germatipniykh korallov jugo-zapadnogo uzbekistana. Acad. Nauk Uzbekskoy SSR Minist. Geol. USSR 5, 58-60 (in Russian).

Santantonio, M., 1994. Pelagic Carbonate Platforms in the geologic record: their classification, and sedimentary and paleotectonic evolution. Am. Assoc. Pet. Geol. Bull. 78, 122-141.

Santantonio, M., Galluzzo, F., Gill, G., 1997. Anatomy and palaeobathymetry of a Jurassic pelagic carbonate platform/basin system: Rossa Mts, Central Apennines (Italy). Geological implications. Palaeopelagos 6 (1996), 123-169. 
Schnyder, J., Baudin, F., Deconinck, J.-F., Durlet, C., Jan du Chene, R., Lathuilière, B., 2000. Stratigraphie et analyse sédimentologique du passage Oxfordien/Kimméridgien dans le Boulonnais. Géol. Fr. 4, 21-37.

Sellwood, B.W., Valdes, P.J., 1997. Geological evaluation of climate General Circulation Models and model implications. Terra Nova $9,75-78$.

Sellwood, B.W., Valdes, P.J., Price, G.D., 2000. Geological evaluation of multiple general circulation model simulations of Late Jurassic palaeoclimate. Palaeogeogr. Palaeoclimatol. Palaeoecol. 156, 147-160.

Sykes, R.M., Callomon, J.H., 1979. The Amoeboceras zonation of the Boreal Upper Oxfordian. Palaeontology 22, 839-903.

Thierry, J., 2000. Early Kimmeridgian. Map 10. In: Dercourt, J., Gaetani, M., Vrielynck, B., Barrier, E., Biju-Duval, B., Brunet, M.F., Cadet, J.P., Crasquin, S., Sandulescu, M. (Eds.), Atlas Peri-Tethys. Palaeogeographical Maps.

Thomas, E.D., 1935. Jurassic corals and hydrozoa, together with a redescription of Astrea caryophylloides Goldfuss. Geol. Palaeontol. Br. Somaliland 4, 21-37.

Turnsek, D., 1997. Mesozoic Corals of Slovenia. Znanstvenoraziskovalni Center Sazu. 512 pp.

van Aarssen, B.G.K., Alexander, R., Kagi, R.I., 2000. Higher plant biomarkers reflect paleovegetation changes during Jurassic times. Geochim. Cosmochim. Acta 64, 1417-1424.

Valdes, P.J., Sellwood, B.W., 1992. A paleoclimate model for the Kimmeridgian. Palaeogeogr. Palaeoclimatol. Palaeoecol. 95, 47-72.

Veizer, J.Y., Goddéris, Y., François, L.M., 2000. Evidence for decoupling of atmospheric $\mathrm{CO}_{2}$ and global climate during the Phanerozoic eon. Nature 408, 698-701.

Vidier, P.P., Marchand, D., Bonnot, A., Fortwengler, D., 1993. The Callovian and Oxfordian of the Boulonnais area in northern France: new biostratigraphic data. Acta Geol. Pol. 43, 169-182.

Weissert, H., Mohr, H., 1996. Late Jurassic climate and its impact on carbon cycling. Palaeogeogr. Palaeoclimatol. Palaeoecol. $122,27-43$.
Wierzbowski, H., 2002. Detailed oxygen and carbon isotope stratigraphy of the Oxfordian in Central Poland. Int. J. Earth Sci (Geol. Rundsch.) 91, 304-314.

Wierzbowski, H., 2004. Carbon and oxygen isotope composition of Oxfordian-Early Kimmeridgian belemnite rostra: palaeoenvironmental implications for Late Jurassic seas. Palaeogeogr. Palaeoclimatol. Palaeoecol. 203, 153-168.

Wilmsen, M., Fürsich, F.T., Seyed-Emami, K., 2003. Revised lithostratigraphy of the Middle and Upper Jurassic Magu Group of the northern Tabas block, east-central Iran. Newsl. Stratigr. $39,143-156$.

Wright, J.K., 1973. The middle and upper Oxfordian and Kimmeridgian Staffin shales at Staffin, Isle of Skye. Proc. Geol. Assoc. 84, 447-457.

Wright, J.K., 1986. A new look at the stratigraphy, sedimentology and ammonite fauna of the Corallian Group (Oxfordian) at south Dorset. Proc. Geol. Assoc. 97, 1-21.

Wright, J.K., 1996a. Perisphinctid ammonites of the Upper Calcareous Grit (Upper Oxfordian) of North Yorshire. Palaeontology 39, 433-469.

Wright, J.K., 1996b. The Amoeboceras faunas of the Upper Calcareous Grit Formation (Jurassic, Upper Oxfordian) of North Yorshire. Proc. York. Geol. Soc. 51, 33-43.

Wright, J.K., 1997. New stratigraphical and palaeoecological data from the Sandsfoot Formation (Upper Oxfordian) of south Dorset. Proc. Geol. Assoc. 109, 15-24.

Wright, J.K., Cox, B.M., 2001. British upper Jurassic stratigraphy (Oxfordian to Kimmeridgian). Geological Conservation Review Series, vol. 21. Joint Nature Conservation Committee, Peterborough, UK. $266 \mathrm{pp}$.

Yamano, H., Hori, K., Yamauchi, M., Yamagawa, O., Ohmura, A., 2001. Highest-latitude coral reef at Iki Island, Japan. Coral Reefs 20,9-12. 